\title{
Coulomb Stress Perturbations Related to the Al Hoceima (Morocco) Earthquakes of 1994 and 2004
}

\author{
Fida Medina \\ Moroccan Association of Geosciences, Commission of Tectonics and Geodynamics, Rabat, Morocco \\ Email: medinafida@yahoo.com
}

Received 7 February 2015; accepted 21 February 2015; published 26 February 2015

Copyright (C) 2015 by author and Scientific Research Publishing Inc.

This work is licensed under the Creative Commons Attribution International License (CC BY).

http://creativecommons.org/licenses/by/4.0/

(c) (i) Open Access

\section{Abstract}

This paper exposes the results of the study of the stress perturbations caused by the Al Hoceima (Morocco) earthquakes of 1994 and 2004 by means of Coulomb modeling. Modeling was based on the compilation of all the studies carried out after both events, including seismological (location and depth of the main shocks and aftershocks), seismotectonic (source parameters, stress field), geodetic (GPS), tomographic and geological ones. It shows that the first earthquake is likely to have induced the second one when adopting appropriate epicenter locations, source and receiver fault planes. In detail, the model shows that motion along the N23E oriented Bousekkour-Aghbal fault in 1994 activated the eastern segment of a previously unknown NW-SE fault located at its southern end, which in turn originated the 2004 earthquake. The model also provides a suitable explanation for the distribution of the aftershock clusters. Finally, an attempt of prediction of the next event shows that it is likely to occur on NE-SW planes located to the NW (Bokkoya and offshore) and SE (reaching the Nekor fault) of the NW-SE fault, while Al Hoceima city should remain in a shadow zone.

\section{Keywords}

Morocco, Seismicity, Al Hoceima, Coulomb Stress Change, Seismotectonics, Seismic Hazard

\section{Introduction}

During the last decades, several research teams have investigated the possible transfer of stress after the occurrence of large/moderate earthquakes to other areas (faults), which may trigger similar events after a relatively short interval, e.g. [1] [2]. The amount of stress transfer is commonly studied using Coulomb stress change (he- 
reafter abbreviated to CSC) modeling; e.g. Coulomb 3 [3], which is a quantitative and graphical method for determining the change in stress within the region located around the main shock [4]. CSC modeling has been applied with success in studies carried out on several seismic zones such as California [4] [5], Japan [6] and Turkey [7], and therefore it appears as an efficient tool for assessing the seismic hazard in a given area.

In northwest Africa, Morocco is located at the limit of the Nubian plate boundary along the Azores-Gibraltar Fault Zone (AGFZ) [8] (Figure 1) and is threatened by moderate and large earthquakes [9]. The largest earthquakes that have been recorded instrumentally since 1934, date of installation of the first seismological station at Averroes Observatory [10], were the "twin" shocks of Al Hoceima on 26 May 1994 (Mw = $5.8-6.0)$, and 24 February $2004(M w=6.3-6.5)$. The first caused two deaths and important material damage [11], while the second caused 628 fatalities and damaged 2539 constructions [12].

The occurrence of closely related large earthquakes in space and time arises two main questions: 1) did the first shock of 26 May 1994 trigger that of 24 February 2004, as already suggested by [13], who used the term "conjugate faults" for the almost-perpendicular rupture planes? And 2) if so, where should the next earthquake occur? In order to assess this issue, CSC modeling was carried out on the Al Hoceima area, as for the "twin" earthquakes $(M=5)$ which hit Rissani (south-eastern Morocco) on 23 and 30 October 1992 [14]. After exposing the general tectonic and seismic characteristics of the area (Section 2), the available data for setting the main constraints for modeling CSC are carefully examined (Section 3). The possible relationship of the 1994 and 2004 earthquakes are then investigated (Section 4) using Coulomb stress change software, and the implications on the seismic hazard of the region are discussed (Section 5).

\section{General Setting}

\subsection{Regional Geodynamic Setting}

Seismicity of the Ibero-Maghrebian area is related to the plate motion of the Nubian and Eurasian plates, which is divergent in the Azores region and right-lateral to convergent eastward e.g. [8] and references therein [9]. Depending on the authors and the used methodology (magnetic anomalies and/or GPS data), the Nubia-Eurasia Eulerian pole (Eurasia fixed) is located between $18.2^{\circ} \mathrm{S}$ and $21.6^{\circ} \mathrm{N}$ and $15.9^{\circ} \mathrm{W}$ and $30.8^{\circ} \mathrm{W}$ [15] [16]. In contrast to the more or less linear Azores-Gibraltar segment of the Nubia-Eurasia plate boundary (Figure 1), the Rif-Betics-Alboran area is a complex mosaic of micro-blocks undergoing variable motion. The Rif and Betics are symmetrical thrust belts undergoing compressional and/or strike-slip regime, while the western Alboran Sea is an extensional (back-arc) basin [17]. The Al Hoceima area is located at the southern segment of a major NNESSW fault zone spanning the eastern Betics e.g. [18], the Alboran Sea [19] and the Central Rif [20]. This shear

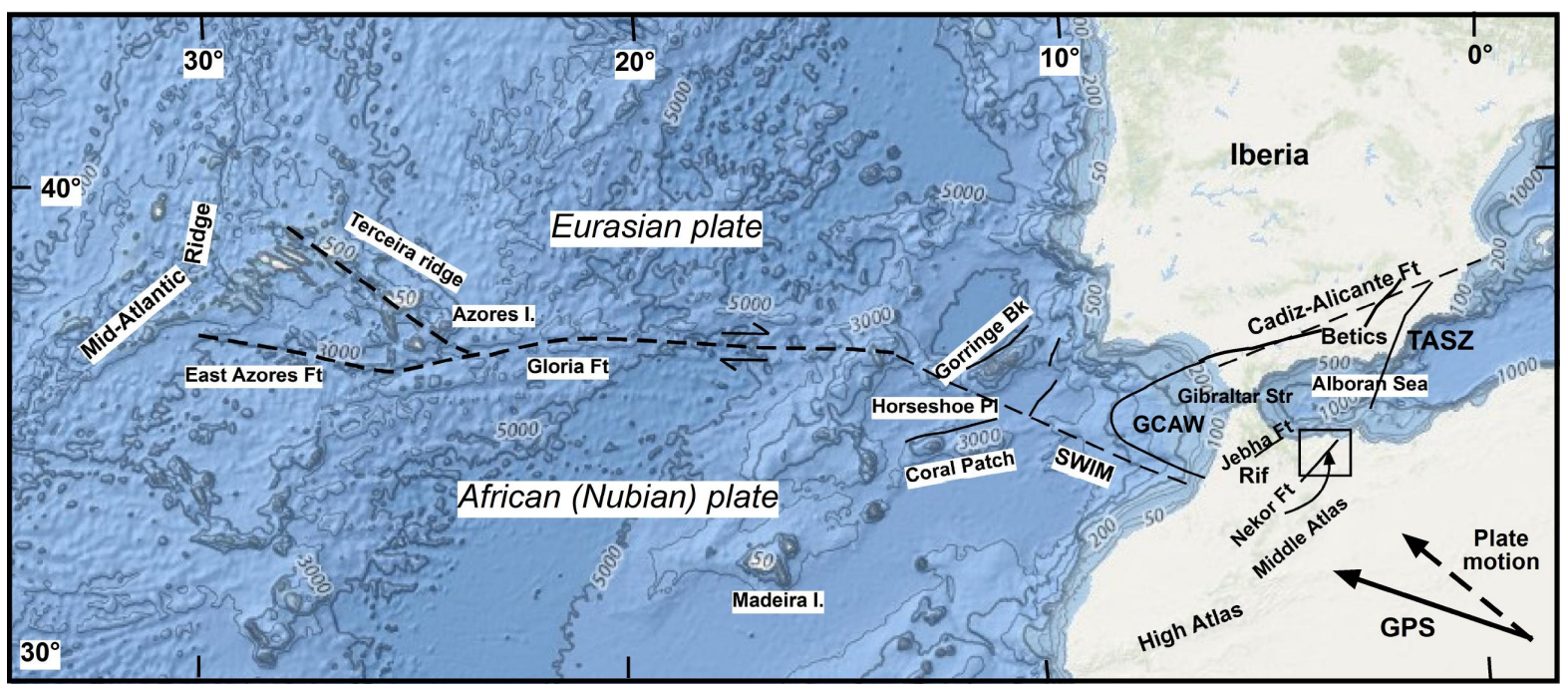

Figure 1. Main structural features along the Azores-Gibraltar Fault Zone and tectonic and seismotectonic setting of Morocco. Bathymetry from NOAA (http://maps.ngdc.noaa.gov/viewers/bathymetry/). Atlantic structures from [8] [88]. GCAW = Gulf of Cadiz accretionary wedge; TASZ = Trans-Alboran Shear Zone. Mean Africa (Nubia)-Eurasia plate motion adapted from [88] and references therein. 
zone, called the Trans-Alboran Shear Zone (TASZ) [21], may represent the eastern termination of the continental western Alboran basin and the eastward transition to the oceanic part (Figure 1). However, the tectonic framework is much more complex in the Alboran basin [22]. The description of the detailed geological history of this area e.g. [17] is beyond the scope of our paper, but knowledge of its present-day kinematics is necessary for understanding its seismic activity and assessing the seismic hazard.

Analyses of GPS data indicate that the direction of convergence is WNW-ESE (Figure 1) with a rate of 4.3 $5.6 \mathrm{~mm} \cdot \mathrm{yr}^{-1}$ [9] and references in their Figure 5 [23]-[25]. The regional model of [24] considers five blocks bounded by fault zones: 1) Iberia and the Atlantic segment north of the AGFZ; 2) Morocco and the Atlantic segment south of the AGFZ; 3) the Betics block; 4) the central Rif and western Alboran block, and 5) the eastern Alboran block. The faults bounding the Betics block are right-lateral, with the exception of the eastern fault, the TASZ, which is left-lateral. Southwards, the presumed faults bounding the central Rif block are left-lateral (the TASZ and the Rif front fault) with the exception of the western fault zone, which is right-lateral. Therefore, with respect to Nubia, a south-westward motion is observed in the central Rif and its foreland [20] [23] [24] [26] in relation to a SW-verging tectonic escape process observed from the surface [27] which may extend at depth [24]. The boundary between both kinematic zones is located along the TASZ, the continental segment of which is located west of Al Hoceima [24]. The amount of slip along this boundary is evaluated at 5.2 to $5.7 \mathrm{~mm} \cdot \mathrm{yr}^{-1}$ [24]. Focal mechanism solutions and analysis of the subsequent state of stress in northern Morocco also indicate a NW-SE convergence [9] [28]-[36] in accordance with the kinematic models.

\subsection{Local Geological Setting and Main Faults}

The city of Al Hoceima is located in the central Rif chain, which runs parallel to the northern coast of Morocco (Figure 2). The most conspicuous structures consist of southward-verging thrust sheets which are, from the upper (northernmost) to the lower (southernmost): 1) the Bokkoya (Palaeozoic and Mesozoic-Cenozoic); 2) the Tiziren unit (Middle Jurassic to Early Cretaceous carbonates and flysch series); and 3) the Ketama metamorphic unit (Cretaceous flysch and limestones). Volcanic rocks are represented by the middle Miocene Ras-Tarf andesites [37] [38]. Unconformable Miocene and younger deposits [39] are encountered in the lower Nekor graben, trending N-S, and in the Boudinar basin, east of Ras Tarf Cape [37] [40]. Offshore, the main structures are the Plio-Quaternary Bokkoya basin, which extends until the Alboran ridge [41] and the lower Nekor basin which is the marine continuation of the onshore one [22] [41] [42].

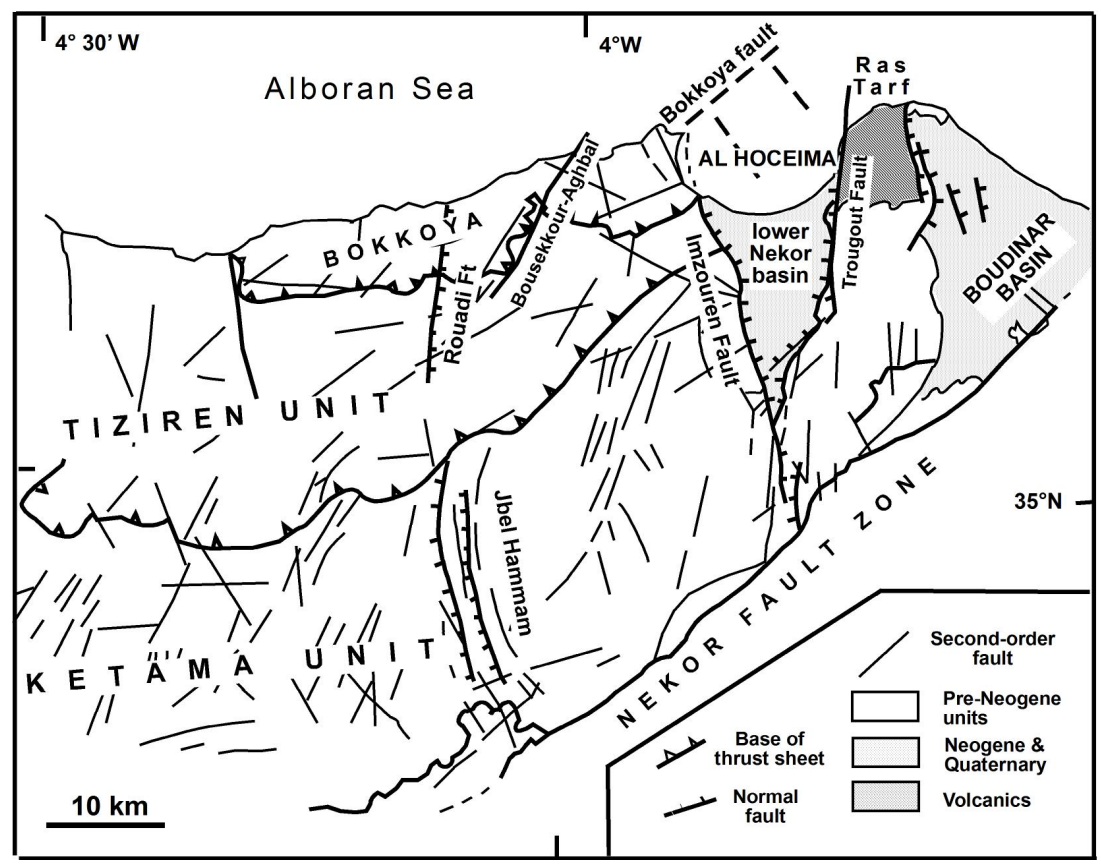

Figure 2. Main geological features of the Al Hoceima area after [28] [37] [42] [46] [47] [89]-[93]. 
The NE-SW left-lateral Nekor fault is the major structure in the area e.g. [43]; however, it has remained seismically inactive since the onset of seismic recordings in Morocco [36] [44] [45]. Other important faults are (Figure 2): 1) The Imzouren (NNW-SSE) and Trougout (N-S) normal faults, which respectively delimit the western and eastern boundaries of the lower Nekor graben; new studies show that the Trougout fault has an oblique (normal/strike-slip) slip rate of $0.73-0.95 \mathrm{~mm} \cdot \mathrm{yr}^{-1}$ since $7 \mathrm{ka}$ [46], and can be followed offshore for about $7 \mathrm{~km}$ with a surface offset [42]; authors [46] calculate a return period for major earthquakes of about 3 ka, which is a relatively long period; 2) The Jbel Hammam fault system (NNW-SSE), consisting of several normal faults with trace lengths of $20 \mathrm{~km}$; 3) The Rouadi fault, a normal fault trending NNE-SSW over $15 \mathrm{~km}$, the eastern block being downthrown; 4) The Bousekkour-Arhbal strike-slip fault (Figure 2), trending NNE-SSW, which crosscuts the whole Bokkoya unit with a sinistral displacement [47]. The latter fault is thought to have been active during the 1994 seismic crisis [11], but radar interferometry and field studies suggest that the rupture did not reach the surface [48]. However, a recent oceanographic survey [42] has shown that the fault can be followed offshore for about $4 \mathrm{~km}$ where it is expressed by an east-dipping normal fault plane (50 m offset of "basement") with a clear $5 \mathrm{~m}$-surface fault scarp. Other offshore faults are those delimiting and affecting the Nekor graben [41], and especially the NNE-SSW striking, $4 \mathrm{~km}$ long, Bokkoya normal fault whose throw is about $50 \mathrm{~m}$ [42].

\subsection{Deep Structure}

Recent multidisciplinary studies e.g. [49] [50] show that the thickness of the crust in northern Morocco decreases northwards from $30 \mathrm{~km}$ in the Rif to $12 \mathrm{~km}$ in the central Alboran basin, whereas the depth of the lithosphere-asthenosphere boundary in the area decreases from 230 - $250 \mathrm{~km}$ in the west, to about $70 \mathrm{~km}$ in the Alboran Sea, the isobaths running roughly N-S. Crustal thinning is accompanied by the development of a large thermal anomaly in the Alboran basin [51]. Around Al Hoceima, the deep structure was mainly studied using seismic tomography [36] [52]-[54]. The results obtained by these authors appear strongly related to the network configuration, and especially to the distance between recording stations; for instance, P-wave velocity maps obtained by [52] show in the layer 5 - $15 \mathrm{~km}$ a large circular ( 100 km diameter), high velocity zone south-east of Al Hoceima, which extends at depth in the layer 15 - $30 \mathrm{~km}$, contiguous to a high velocity zone. The boundary of both zones runs NNW-SSE across the lower Nekor graben. Authors [53] inferred low velocity zones within the layer $5 \mathrm{~km}$ beneath the Nekor graben and within the lower crust in the continental area, whereas the most important high velocity zone is located south of Al Hoceima city within the layer $10 \mathrm{~km}$. Tomographic maps of [54] show a low-velocity zone at $15 \mathrm{~km}$ depth near Al Hoceima; however, the resolution is not appropriate for determining better orientations. Instead, the higher resolution tomography obtained by [36] shows better constrained velocity zones at 5 - $15 \mathrm{~km}$ depth, with a determinable orientation.

\subsection{Seismicity}

Historically, the Al Hoceima area suffered numerous strong earthquakes as shown by the earliest earthquake catalogues [44] [55]. The best documented events were recorded in 1522, 1624, 1790-1791, 1795 and 1800-1803 (M 6?), 1848, 1910-1914. Since the onset of the instrumental period, the early and following authors e.g. [44] [56]-[58] observed that seismicity is largely scattered on the scale of the Betic-Rif Arc. On the base of the data from NEIC, the epicenters of events with magnitudes $>3$ from $1^{\text {st }}$ January 1960 to 3 October 2014 in the Al Hoceima area are shown in Figure 3. Most of the earthquakes are shallow, and their magnitudes are generally moderate, except for the 1994 and 2004 events. The epicenters are clearly aligned along a NNE-SSW trend parallel to the TASZ; however, on the regional scale, epicenters of some well-constrained micro-earthquakes and aftershocks of large events are clearly aligned along NNE-SSW, NNW-SSE and WNW-ESE trends [11] [36] [41] [59]-[61]. The seismic flux (the seismic moment released per year and per unit area) calculated from a 104 year period is one of the largest in the Western Mediterranean, reaching more than $10^{19} \mathrm{dyne} \cdot \mathrm{cm}^{\circ} \mathrm{km}^{-2} \cdot \mathrm{yr}^{-1}[9]$.

\subsection{Focal Mechanisms and Ground Surface Motion}

Since the 1970's and until 2007, at least 100 focal mechanisms were determined for large and moderate earthquakes $(\mathrm{M}>3.5)$ of the Al Hoceima area using first motion polarities of P-waves, waveform analysis and moment tensor inversion [62]. Among these, a large number of solutions were determined by seismological agencies (IGN, IAG, MED, INGV) for the aftershocks of the 2004 earthquake. Most fault-plane solutions, including 


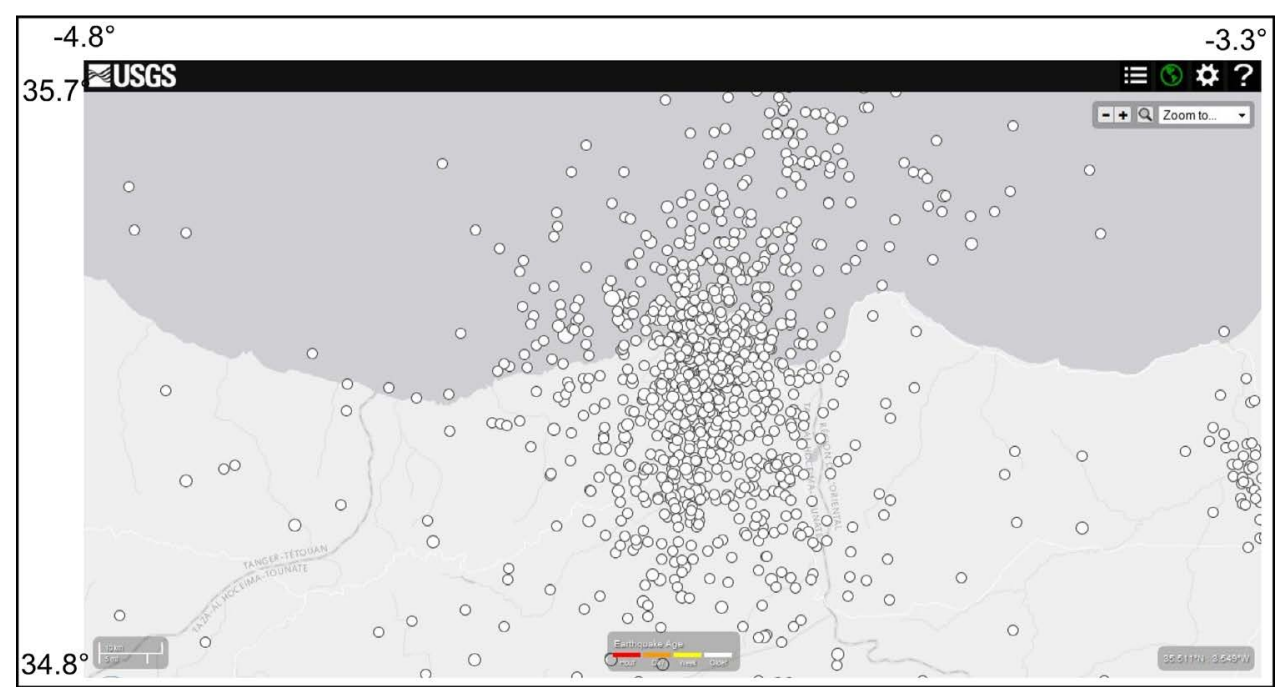

Figure 3. Epicenters of earthquakes with magnitudes $>3$ recorded by NEIC (USGS) from $1^{\text {st }}$ January 1960 to 3 October 2014 in the $\mathrm{Al}$ Hoceima area.

the largest aftershocks of the two major earthquakes, correspond to strike-slip faulting with a normal component and to normal faulting (Figure 4). A few solutions correspond to reverse faulting or to strike-slip motions with reverse component. The $P$ axes are distributed in the NW and SE quadrants with variable plunge. The solutions obtained for interseismic periods [28] [45] [63] [64], also indicate that the dominant regime is strike-slip/normal, with a general lack of pure reverse mechanisms. The $P$ axes are distributed along a NW-SE great circle, with largely variable plunges, whereas $T$ axes are NE-SW to ESE-WNW with a shallow plunge [28] [65].

From GPS data listed by [23] [24], the general displacements with respect to fixed Africa calculated from the East and North components, are variable: east of the TASZ, permanent station MELI shows a SSE (N173) small motion (1.61 mm: $\left.\mathrm{yr}^{-1}\right)$ during the period 1999-2007, while nearby temporary station MDAR shows a NNE (N20) moderate motion $\left(2.24 \mathrm{~mm} \cdot \mathrm{yr}^{-1}\right)$ during the period 1999-2004. West of the trace of the TASZ, the motion at temporary stations BBFH (period 1999-2004) and KTMA (period 1999-2005) is SSW (N203 and N229 respectively), and the linear velocity is significant ( 3.31 and $3.7 \mathrm{~mm} \cdot \mathrm{yr}^{-1}$ respectively).

\section{Methodology: Modeling Coulomb Stress Change and Constraints}

\subsection{Principle}

Coulomb stress change is best expressed by the equation e.g. [4]:

$$
\Delta \sigma_{c}=\Delta \tau-\mu, \Delta \sigma_{N}
$$

where $\Delta \sigma_{c}, \Delta \tau$ and $\Delta \sigma_{N}$ are, respectively, the coseismic changes in Coulomb stress, shear stress and normal stress, and $\mu^{\prime}$ is the effective coefficient of friction, e.g. [66] and references therein, which corresponds to $\mu^{\prime}=\mu(1-B)$ where $B$ is Skempton's coefficient, comprised between 0.5 and 0.9.

Modeling was carried out on the region of coordinates $34.8^{\circ} \mathrm{N}-35.7^{\circ} \mathrm{N} \times 3.3^{\circ} \mathrm{W}-4.8^{\circ} \mathrm{W}$ with the help of Coulomb 3.2 software [3]. In a first step, we considered the fault related to the 1994 earthquake as the source fault and that of the 2004 shock as the receiver fault. In a second step, we considered the effects of the 2004 earthquake on the nearby region. CSC was resolved both on optimal strike-slip planes and on chosen particular planes parallel to the considered receiver faults. A discussion on this point can be found in [67]. The following subsections expose in detail the model constraints which are necessary as input data to the construction of the model, such as the regional state of stress and the source parameters including the location of the epicenter, the nucleation depth, length and width of the rupture and aftershocks location.

\subsection{Model Constraints}

The model constraints are based on a large database collected after the 1994 and 2004 earthquakes by numerous 

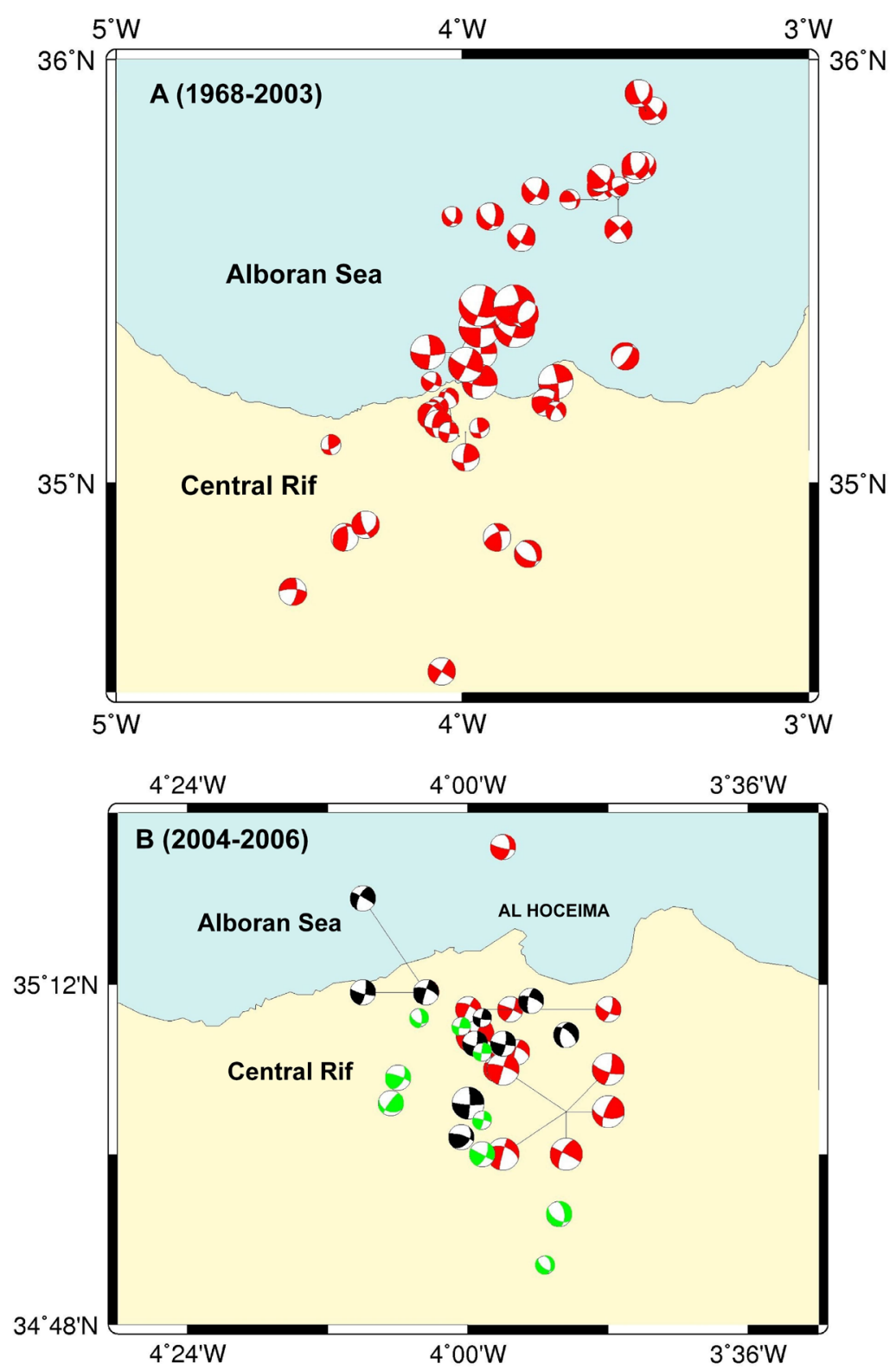

Figure 4. Focal mechanisms of the Al Hoceima area from 1959 to 2006 after [65].

international research teams that carried out studies on the source parameters of both earthquakes, using various methods such as classical seismic and micro-seismic surveys [11] [12] [36] [41] [68] [69], seismic wave analyses [33] [36] [70], radar interferometry [13] [61] [71]-[73], GPS measurements and SPOT images interpretation [61] [73] and seismic tomography [36].

\subsubsection{Regional State of Stress}

The state of stress in the Al Hoceima and surrounding region, compiled in Table 1, was determined by several authors from background microseismicity [28], from the aftershocks of the seismic crises of 1994 [11] and 2004 [36] [69] and from general seismicity [28] [31]-[35]. The determinations are mainly based on focal mechanism solutions using the right dihedra method [74] [75], and/or numerical stress inversion methods [76]-[83]. The state of stress obtained for three sets of moderate to large earthquakes (isolated, 1994 and 2004) show similar orientation of axes, reflecting a strike-slip regime, with $\sigma_{1}$ and $\sigma_{3}$ horizontal and trending NNW-SSE $\left(\mathrm{N} 140^{\circ} \mathrm{E}\right.$ to $\mathrm{N} 156^{\circ} \mathrm{E}$ ) and ENE-WSW (N42 ${ }^{\circ}$ to $\mathrm{N} 65^{\circ} \mathrm{E}$ ) respectively. For micro-earthquakes (shocks of magnitude 1 to 3 ), 
Table 1. State of stress determined by various authors for the Al Hoceima area.

\begin{tabular}{lcccccccc}
\hline References & $\mathrm{N}$ & $\begin{array}{c}\text { Numerical } \\
\text { Method }\end{array}$ & Az. & Pl. & Az. & Pl. & $\Phi$ & Database \\
\hline$[32]$ & 13 & {$[74]$} & 336 & 09 & 245 & 03 & 0.953 & Moderate teleseisms \\
{$[32]$} & 8 & {$[74]$} & 140 & 19 & 042 & 20 & 0.22 & 1994 crisis \\
{$[32]$} & 16 & {$[74]$} & 326 & 01 & 056 & 04 & 0.3 & 2004 crisis \\
{$[33]$} & 40 & {$[82]$} & 354 & 22 & 088 & 22 & 0,66 & $2002-2005$ \\
{$[34]$} & 16 & {$[81]$} & 335 & 03 & 061 & 12 & 0,29 & 2004 crisis \\
{$[35]$} & 31 & {$[82]$} & 293 & 14 & 195 & 29 & 0.50 & 2004 crisis \\
{$[36]$} & 131 & {$[78]$} & 337 & 23 & 246 & 03 & 0.7 & 2004 crisis \\
{$[36]$} & 37 & {$[78]$} & 334 & 44 & 246 & 02 & 0.9 & 1989 microseisms from [45] \\
\hline
\end{tabular}

the state of stress is extensional in the Imzouren area and strike-slip elsewhere [28]. As discussed in detail previously [11] [28] [32], large to moderate earthquakes are related to the regional state of stress driven by plate and micro-plate motions, while micro-earthquakes only reflect a local state of stress related to block adjustments.

\subsubsection{The 26 May 1994 Earthquake}

Characteristics and ground effects. The main shock of 26 May 1994, occurred at 8 h 27 min UTC. Various epicenter locations were proposed for the main shock (Figure 5), but all authors agree that it was located west of Al Hoceima, probably near- or offshore. The magnitude was $M d=5.6(M w=6.0)$, and the hypocentral depth was $13 \mathrm{~km}$. The values of the seismic moment Mo vary from $1.1 \times 10^{17} \mathrm{~N} \cdot \mathrm{m}$ (waveform analysis [70]) to $2.1 \times 10^{18}$ $\mathrm{N} \cdot \mathrm{m}$ (InSAR; [72]). As reported by [11], the ground effects observed after the main shock consisted of decametric-scale N40 to N50 en échelon cracks, and landslides along the coastal cliffs west of Al Hoceima and more inland. No unequivocal surface faults were observed during the survey. The isoseismal map elaborated by [11] based on EMS 1992 scale shows a maximum damage area (intensity VIII-IX EMS) trending NNE-SSW from $35.25^{\circ} \mathrm{N} \times 4^{\circ} \mathrm{W}$ to $35.12^{\circ} \mathrm{N} \times 4.15^{\circ} \mathrm{W}$.

Focal mechanisms. At least 9 fault-plane solutions were determined by various seismological centers (USGS, CSEM and Harvard) and authors [11] [70] [72] for the main shock of 1994. Solutions obtained by moment tensor inversion (USGS, Harvard, CSEM, [84]) or waveform modeling [70] [72] show strike-slip motion with a slight normal component. The solution proposed by [11] on the base of first motions includes a reverse component. Reference [70] suggested that the main event consisted of two sub-events, the mechanism of sub-event 2 also showing a reverse component. Seven solutions determined for the aftershocks correspond to strike-slip/ normal faulting, except for the one of 3 June at $8 \mathrm{~h} 57 \mathrm{~min}$, which shows a reverse component as for the main shock [11]. The $T$-axes are almost-horizontal and are oriented NE-SW to ENE-WSW; the $P$-axes have a moderate plunge $\left(60^{\circ}\right.$ maximum).

Location of fault rupture. In addition to the source parameter determinations from seismic data [70], relatively concordant radar interferometry analyses performed by [13] [72] suggest (Table 2) that the ground deformation can be best modeled by a N23 striking, $10-16 \mathrm{~km}$ long, $10-15 \mathrm{~km}$ wide fault dipping east, with a 0.6 - $0.8 \mathrm{~m}$ left-lateral slip. The rupture area remains beneath the surface (depth $\geq 2 \mathrm{~km}$ ).

Aftershock sequence. The DPG (Institut Scientifique) temporary network of 7 short-period $(1 \mathrm{~Hz})$ analogical stations installed by [11] from 27 May to 9 June 91994 recorded 512 events located onshore, whose highest magnitude was $M d=4.4$. The 68 best constrained events correspond to 2 - $18 \mathrm{~km}$ deep, NNE-SSW trending cluster of aftershocks, which is largely distributed over a $30 \times 10 \mathrm{~km}$ region that matches the maximum damage area (Figure 6). The aftershocks appear southward of the epicenter of the main shock when the latter is taken to be offshore. These authors state that the shift may be due either to errors on the determination of the main shock epicenter, or to sensitivity threshold of the seismic stations, which would not record weak events located offshore. Among the vertical sections oriented at different angles to the NNE-SSW trending cluster, the one oriented WNW-ESE, perpendicular to the cluster, suggests that the foci are concentrated along a plane with a steep dip to the east-southeast [11] their figure 8. The aftershock sequence of the 1994 earthquake was also studied by [41], based on teleseisms recorded by the permanent digital stations of the CNRST (Morocco), and 


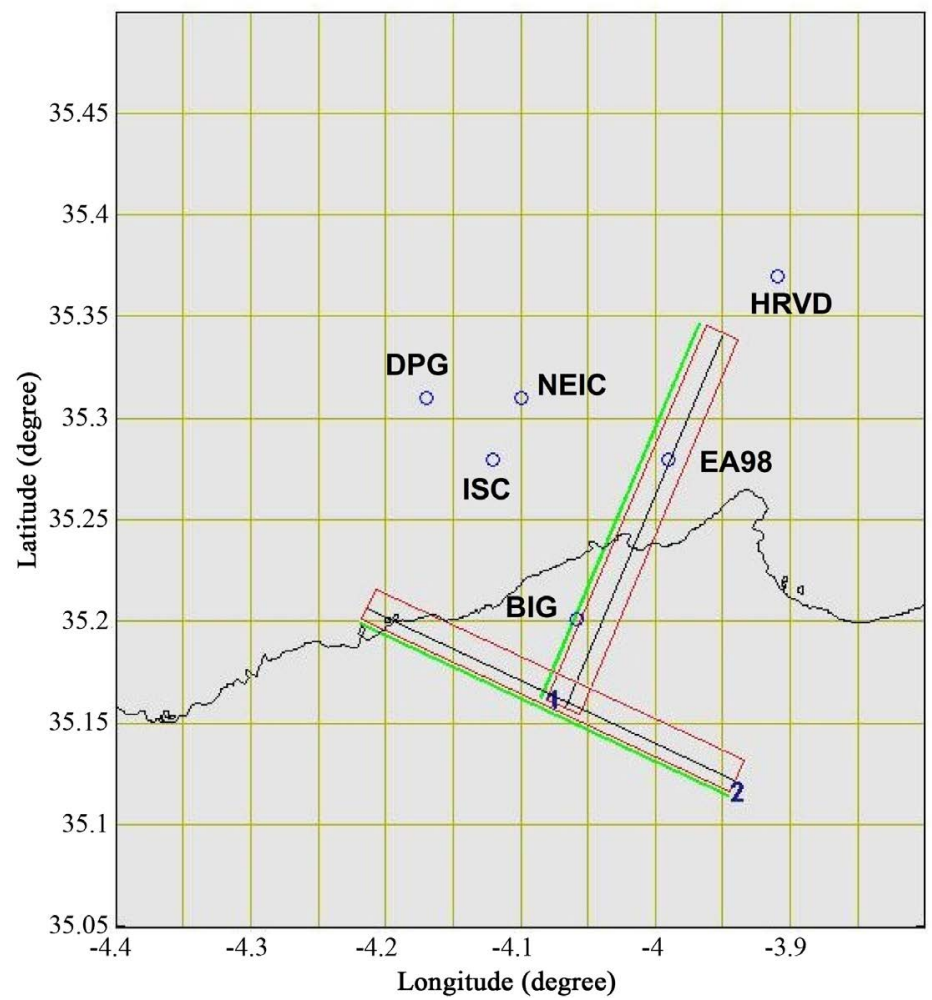

Figure 5. Location of the epicenter of the May 1994 shock according to different seismological agencies and fault traces used for Coulomb stress modeling.

Table 2. Fault parameters determined by several authors for the Al Hoceima earthquakes of 1994 and 2004. Data in bold characters were those taken into account as input parameters for the CSC model.

\begin{tabular}{|c|c|c|c|c|c|c|c|c|c|c|c|c|}
\hline Authors & Method & Fault & Lat & Long & Strike & Dip & Rake & $\begin{array}{l}\text { Depth } \\
(\mathrm{km})\end{array}$ & $\begin{array}{l}\text { Length } \\
(\mathrm{km})\end{array}$ & $\begin{array}{l}\text { Width } \\
(\mathrm{km})\end{array}$ & $\begin{array}{l}\text { Slip } \\
\text { (m) }\end{array}$ & $\begin{array}{c}\text { Mo } \\
\left(\times 10^{18} \mathrm{~N} \cdot \mathrm{m}\right)\end{array}$ \\
\hline \multicolumn{13}{|l|}{$\begin{array}{l}26 \text { May } \\
1994 \text { event }\end{array}$} \\
\hline \multirow{3}{*}[70]{} & WA (sub-event I) & $\begin{array}{l}\mathrm{L} \\
\mathrm{R}\end{array}$ & & & $\begin{array}{c}329.9 \\
72\end{array}$ & $\begin{array}{l}77 \\
74\end{array}$ & $\begin{array}{c}-45 \\
-163\end{array}$ & 6.8 & $0.9-1$ & $0.9-1$ & 1.09 & 0.11 \\
\hline & WA (sub-event II) & $\begin{array}{l}\mathrm{L} \\
\mathrm{R}\end{array}$ & & & $\begin{array}{l}355.0 \\
264\end{array}$ & $\begin{array}{l}69 \\
89\end{array}$ & $\begin{array}{l}2.5 \\
168\end{array}$ & 8.0 & $2.9-3$ & $2.9-3$ & 0.53 & 0.48 \\
\hline & SA & & & & & & & & $13.6(\mathrm{c})$ & 13.6 (c) & 0.15 & 0.7 \\
\hline [72] & InSAR & $\mathbf{L}$ & 35.201 & -4.058 & 23.3 & 86.9 & -1.2 & $2-12$ & 9.9 & 10 & 0.69 & 2.1 \\
\hline [13] & InSAR & & 35.202 & -4.039 & 23 & 80 & -6 & $6-10$ & 16 & 15 & 0.8 & 2.0 \\
\hline \multicolumn{13}{|l|}{$\begin{array}{l}24 \text { February } \\
2004 \text { event }\end{array}$} \\
\hline [13] [71] & InSAR & (R) & 35.127 & -3.993 & $322^{*}$ & 87 & -161 & $6-10$ & 19 & 14 & 2.7 & 6.6 \\
\hline \multirow{2}{*}{ [72] } & \multirow{2}{*}{ InSAR } & B (R) & 35.137 & -3.986 & 295.4 & 87.4 & -179.2 & 2.1-18 & 8.8 & 16 & 1.4 & 6.2 \\
\hline & & L (synth) & & & 300 & 90 & -180 & $2-18$ & 10 & 16 & 1 & - \\
\hline \multirow{2}{*}[61]{} & \multirow{2}{*}{ InSAR, SPOT } & A1 (L) & 35.122 & -3.959 & 10 & 88 & 1.3 & 0.5 & 9 & 11.5 & 0.92 & 2.8 \\
\hline & & A2 (R) & 35.134 & -4.028 & 312 & 88 & -179 & 3.0 & 15 & 9.0 & 0.76 & 3.08 \\
\hline [73] & MTInSAR & & 35.144 & -3.983 & 298.2 & 78.4 & 180 & $2.8-15$ & $\sim 12^{* *}$ & 12.2 & 1 & 3.65 \\
\hline [36] & WA (sub event 1 ) & & 35.128 & -3.955 & 295 & 89 & 170 & 7 & & & & \\
\hline
\end{tabular}

"curved fault trace, ${ }^{* *}$ determined graphically by the present author from figures. 
the PDE of the USGS epicenters recorded from January 1994 to June 1995. The aftershock cluster appears to the east of that shown by [11]. Authors [41] concluded that the observed shift to the west of PDE locations with respect to CNRST ones may be due to "an area of anomalous velocities, coupled with a relative dearth of seismic stations on the African continent for good azimuthal control". Authors [72] also studied the aftershock sequence of the 1994 shock. From ISC and PDE (USGS) files, only 9 well-constrained events were relocated; among which 4 are located along the NNE-SSW fault trace, whereas the other 5 are located either to the NW, to the SW and to the SSE.

\subsubsection{The 24 February 2004 Earthquake}

Characteristics and ground effects. The main shock of 24 February 2004 occurred at 2 h 27 min UTC. The epicenter of the earthquake was located southeast of Al Hoceima at Ait Kamra near Imzouren $\left(35.28^{\circ} \mathrm{N} \times 3.99^{\circ} \mathrm{W}\right)$. Its magnitude $M d$ was $6.3(M w=6.2)$, and the hypocentral depth was $6 \mathrm{~km}$. The seismic moment Mo was estimated by [60] at $1.8 \times 10^{18} \mathrm{~N} \mathrm{~m}$. From analysis of body wave forms at teleseismic distances, [60] found a complex rupture process along a NNE-SSW fault with bilateral rupture formed by 4 shallow sub-events, with rupture propagating towards the north. However, no numerical data were published to date. Authors [33] studied the rupture process using regional ASTM. Their results involve 2 sub-events separated by 3 sec, located on parallel faults striking N11, the second sub-event being located southwest of the first. The ground effects observed after the main shock consist of variable size (centimetric to kilometric) cracks oriented ENE-WSW to NNE-SSW, along a 20-km-wide corridor south of Al Hoceima, and metric to decametric landslides [48] [61] [68]. The isoseismal map based on MKS scale shows a maximum damage area (intensity VIII-IX) trending NE-SW from $35.20^{\circ} \mathrm{N} \times 3.75^{\circ} \mathrm{W}$ to $35.05^{\circ} \mathrm{N} \times 4.10^{\circ} \mathrm{W}$ [68].

Focal mechanisms. Focal mechanisms determined for the main shock from moment tensor inversion (USGS, Harvard, LDG) show nodal planes oriented NNE-SSW and WNW-ESE with ESE and SSW steep dips respectively. Mechanisms of the strongest aftershocks, determined by IGN (Spain) correspond to strike-slip faulting with a reverse component mainly, and to reverse faulting (Figure 4). Mechanisms of the weakest aftershocks also correspond to strike-slip faulting with mainly a normal component [36] [69]. P-axes concentrate around azimuth $\mathrm{N} 330^{\circ} \mathrm{E}$.

Location of fault rupture. In order to find the location of the fault trace for this event, radar interferometry analyses were performed by several teams [13] [61] [71]-[73]. Their results are summarized in Table 2. Authors [13] [71] indicate that the ground deformations are best modeled by a NW-SE curved-shape, $19 \times 14 \mathrm{~km}$ fault dipping $87^{\circ} \mathrm{NE}$, with a maximum $2.7 \mathrm{~m}$ right-lateral slip without reaching the surface. Authors [72] also favor a NW-SE, $10 \times 18 \mathrm{~km}$ fault dipping 87.4 NE, with a 1.4 right lateral slip. Authors [61] suggested a double rupture along two sub-vertical faults oriented N10 $(9 \times 11.5 \mathrm{~km})$ and N312 $(15 \times 9 \mathrm{~km})$, with displacements of $0.92 \mathrm{~m}$ (left-lateral) and $0.76 \mathrm{~m}$ (right-lateral) respectively. However, it is somewhat surprising that the determined NW-SE fault trace does not match the NW-SE alignment of numerous aftershock epicenters, but appears shifted to the south. Finally, [73] arrive to similar fault parameters using MTInSAR.

Aftershock sequence. Among the several aftershock surveys conducted using teleseismic, regional permanent and/or portable seismographs e.g. [12] [72], the most detailed survey carried out from 28 March to 10 April [36] [61] [69] clearly shows that the 650 aftershocks are $1-16 \mathrm{~km}$ depth and aligned along NNE-SSW and NW-SE trends. The NNE-SSW cluster is located in the southward continuation of the suggested fault, whereas the NW-SE clusters are located parallel to the NW-SE plane. Other alignments appear to the south-east. Early aftershocks located with the help of the permanent seismological stations are aligned NW-SE but are also located to the NE of the proposed plane.

Surface ground motion. GPS data from [61] indicate that, taking into account the annual displacement with respect to fixed Africa (see Section 2.5), station BBFH, located $30 \mathrm{~km}$ to the west of Al Hoceima, underwent a $30 \mathrm{~mm}$ displacement toward the west, while station MDAR, located $40 \mathrm{~km}$ to the southeast of Al Hoceima, only showed a $5 \mathrm{~mm}$ displacement. Finally, comparison of two SPOT5 images shows that the co-seismic rupture could not have exceeded $5-10 \mathrm{~cm}$ at the surface.

\subsection{Summary of Input Parameters}

\subsubsection{The 1994 Source Fault (Fault 1)}

Epicenter location and focal depth. Based on the field survey of [11], we chose the epicenter located around 
$35.26^{\circ} \mathrm{N} \times 4.0^{\circ} \mathrm{W}$ for the 1994 earthquake, which is situated on the chosen fault plane. The adopted depth is 7.5 $\mathrm{km}$.

Fault parameters. For the 1994 shock (the source fault), we calculated CSC simplifying the parameters exposed by [72]: strike $\mathrm{N}^{\circ} 3^{\circ}$; dip $85^{\circ}(\mathrm{E})$; length $8 \mathrm{~km}$; width $8 \mathrm{~km}$ (2 - $10 \mathrm{~km}$ depth); mean displacement $0.7 \mathrm{~m}$ left-lateral (when uniform), which lead to a seismic scalar moment of about $1.4 \times 10^{25} \mathrm{dyn} \cdot \mathrm{cm}\left(1.4 \times 10^{18} \mathrm{~N} \cdot \mathrm{m}\right)$ and a moment magnitude of $\sim 6.0$. In order to avoid in excess concentration of stress at the tips of the fault, the plane was tapered into 5 patches as recommended by the Coulomb 3 tutorial.

Stress orientation and magnitude. CSC calculations were carried out taking into account the regional state of stress, derived from our R4DT determination for the Al Hoceima area [28] [32]: $\sigma_{1}$ and $\sigma_{3}$ horizontal at $150^{\circ} \mathrm{E}$ and $\mathrm{N} 60^{\circ} \mathrm{E}$ respectively. The stress magnitudes used by software Coulomb are 100 bar for $\sigma_{1}$ at the surface; 0 bar for $\sigma_{3}$ and 30 bar for $\sigma_{2}$. No vertical gradient was taken into account. The CSC calculation depth is $7.5 \mathrm{~km}$.

Fault strength parameters. We used the default values recommended by the Coulomb 3 software. These are $8 \times$ $10^{5}$ bar for Young modulus; 0.25 for Poisson's ratio, and 0.8 for the coefficient of friction.

\subsubsection{The 2004 Source Fault (Fault 2)}

Epicenter location and focal depth. For the 2004 shock, a source with coordinates $35.13^{\circ} \mathrm{N} \times 3.95^{\circ} \mathrm{W}$ at a depth of $7.5 \mathrm{~km}$ was used.

Fault parameters. Fault parameters (Table 2) are also those calculated by [72]: strike N295 ; dip $87^{\circ} \mathrm{N}$; length $10 \mathrm{~km}$; width $10 \mathrm{~km}$ (2 - $12 \mathrm{~km}$ depth) and $1 \mathrm{~m}$ of right-lateral displacement, which lead to a seismic scalar moment of $3.2 \times 10^{25}$ dyn.cm and a moment magnitude $M w=6.3$. The fault trace was constrained by recent aftershock data published by [36] repository material.

Stress orientation and magnitudes and fault strength parameters are the same than those used in the previous case.

\section{Results}

\subsection{CSC after the 1994 Earthquake}

Figure 6(A) illustrates the CSC distribution for optimal strike-slip planes after $0.7 \mathrm{~m}$ left-lateral slip on fault 1 . It clearly shows an increase ( $\geq 5$ bar, saturation value) in the magnitude of the stresses at the tips of the fault, and a decrease ( $\leq-5$ bar, saturation value) across the plane along a NE-SW oriented zone. Most of the epicenters of the aftershocks taken from [11] (for clarity, only the 80 first ones recorded from 27 to 30 May are shown) plot in the positive CSC zone oriented at a small anti-clockwise angle from the fault, but a large number plot in a negative CSC zone. The receiver fault undergoes positive CSC mainly at its centre.

In the case of CSC resolved on the N20E (=N200E) vertical planes oriented parallel to the main fault (Figure 6(B)), all aftershock epicenters fall within the large negative CSC area situated on both fault blocks. However, a small positive CSC zone affects the receiver fault at its eastern tip.

Finally, when CSC is resolved for specified N300E (N120E) striking dextral strike-slip planes (Figure 6(C)), parallel to the receiver fault, almost-all aftershocks fall in a negative CSC zone. The receiver fault also undergoes positive CSC all along its eastern segment.

\subsection{CSC after the 2004 Earthquake}

Figure 7(A) shows the Coulomb stress distribution after $1 \mathrm{~m}$ right-lateral slip on Fault 2 resolved on optimal strike-slip planes. An increase ( $\geq 5$ bar, saturation value) in the magnitude of the stresses is observed at the tips of the fault, whereas a decrease ( $\leq-5$ bar, saturation value) can be seen across the plane along a NE-SW direction.

The aftershock epicenters determined by [36] (only the first 300 ones from 29 March to 6 April were plotted for clarity) fall within a Coulomb stress increase area (Figure $7(A)$ ). However, the cluster at $35.15^{\circ} \mathrm{N} \times 4.05^{\circ} \mathrm{W}$ falls in a shadow zone, which does not match the Coulomb stress change. No changes are observed when the CSC is resolved on planes which are parallel to the main fault (Figure $7(B)$ ), and the cluster at $35.15^{\circ} \mathrm{N} \times$ $4.05^{\circ} \mathrm{W}$ remains in the same CSC decrease zone.

When CSC is resolved on sinistral planes striking N20E, no important changes are observed with respect to the previous panel (Figure 7C). Finally, CSC resolved on normal fault planes such as found by [36] at the 

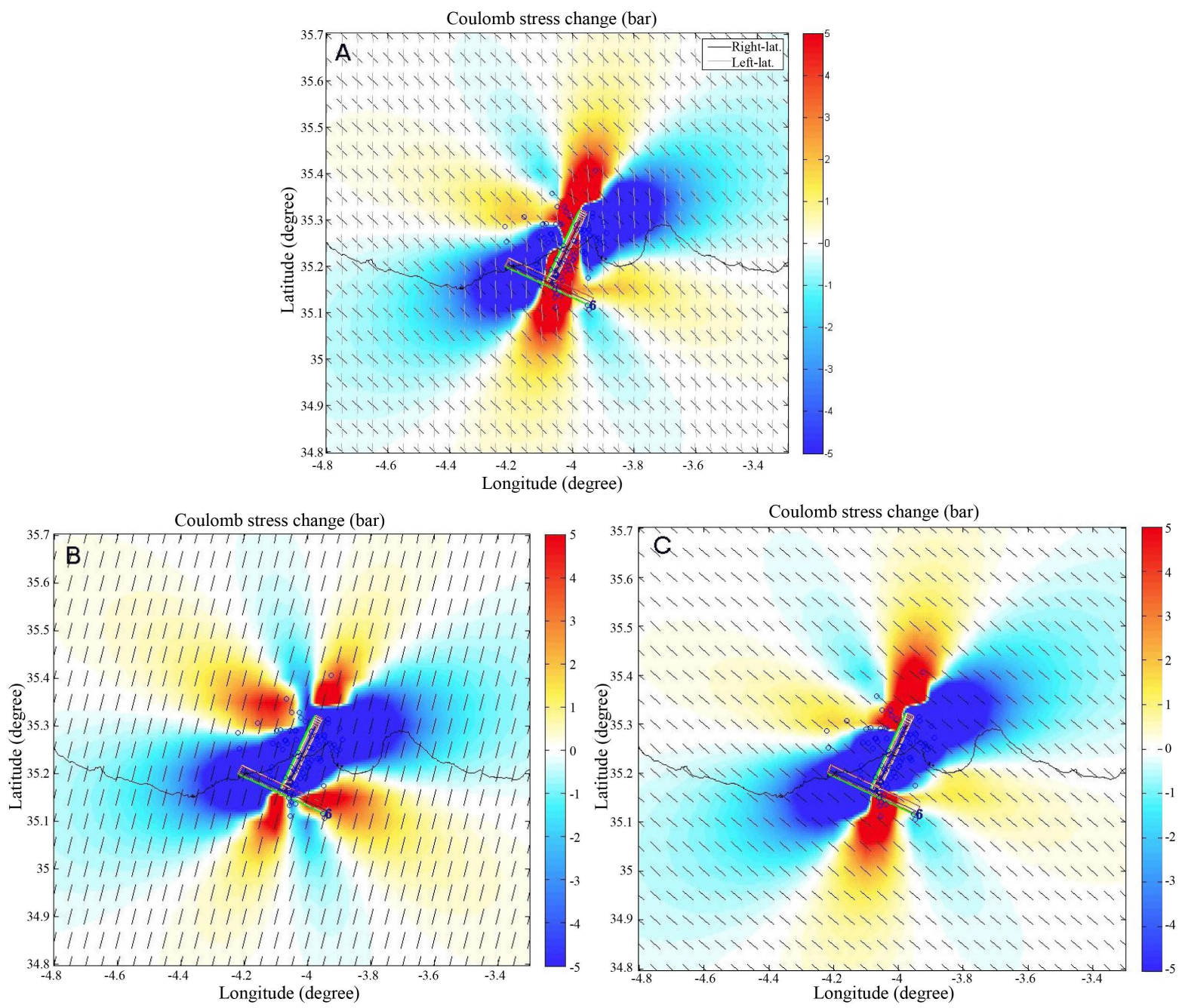

Figure 6. Results of CSC modeling of the 1994 earthquake: (A) On optimally oriented strike-slip planes; (B) On planes parallel to the main fault; (C) On planes oriented N300 (or N120).

eastern aftershock cluster (Figure 7(D)) shows that the aftershocks also fall in the increase zone, which is in conformity with aftershock triggering.

\section{Discussion}

\subsection{Robustness of CSC Modeling in Al Hoceima Area}

As indicated in section 1, CSC modeling has already been successfully used for studying local and regional stress changes after major earthquakes, as well as for predicting the loci of occurrence of future ones in several seismic areas in the world. In the present study, CSC modeling was applied to the $\mathrm{Al}$ Hoceima region, which is an area of distributed moderate seismicity with relatively short faults.

From our results, CSC modeling was successful in helping understand several observations:

1) CSC after the 1994 earthquake may have led to a stress increase along the eastern segment of the WNWESE fault responsible for the 2004 earthquake; therefore, as for the Rissani twin earthquakes of 1992 [14], the model provides a consistent explanation for the space relationship between both events.

2) Aftershock distribution and reactivation of optimally oriented planes after both earthquakes are also successfully accounted for by CSC modeling.

However, although the geometrical parameters seem to be relatively well constrained on the base of the data taken from the numerous studies of the Al Hoceima earthquakes, there are intrinsic parameters which remain 

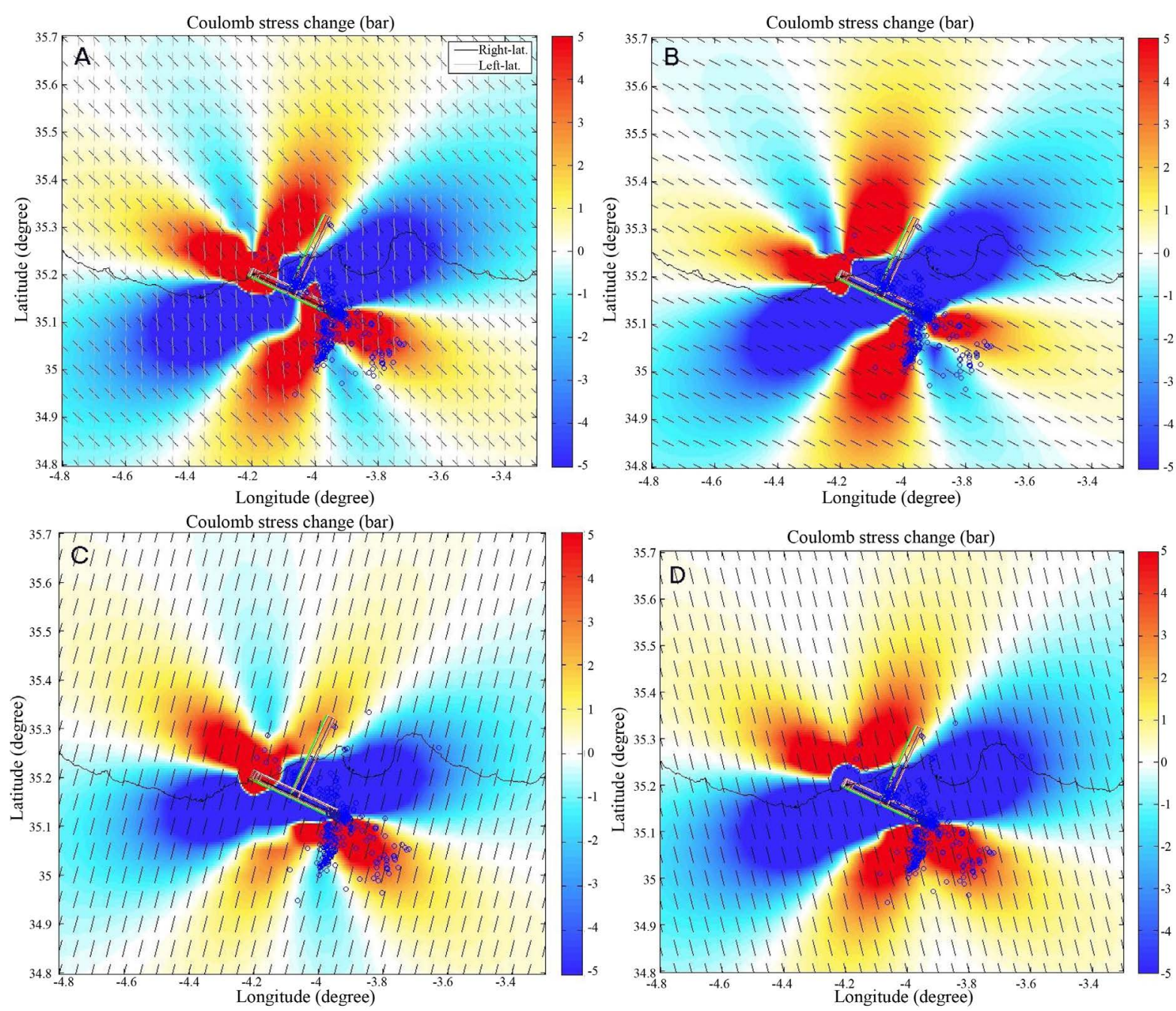

Figure 7. Results of CSC modeling of the 2004 earthquake: (A) On optimally oriented strike-slip planes; (B) On planes parallel to the main fault; (C) On planes oriented N20; (D) On NNW-SSE oriented normal planes.

less constrained. This is the case of the variable input values suggested by the software such as the friction coefficient, the regional stress magnitude and its variability with depth, which are beyond the scope of the present article, focused on regional aspects.

\subsection{Seismogenic Faults in the Al Hoceima Area}

One of the major problems for constraining the relationship between earthquakes and faults in the Central Rif is that a few ruptures were observed during both events [11] [36] [48] [68], although rupture has been proved to reach the surface offshore [42], so the faults remained blind and their pattern was only delineated afterwards using focal mechanism solutions, aftershock distribution and radar interferometry. Indeed, the WNW-ESE fault responsible for the 2004 earthquake had no previous morphological or deep features which could have helped mapping it.

The post-seismic field survey of the 2004 earthquake [48] suggests that there seems to be some vertical partitioning of deformation, with thrust sheets at the surface and strike-slip faults at depth. However, this is not true everywhere, because it is obvious that some faults reach the surface, such as the Trougout-Bou Haddoud, Rouadi, Bousekkour-Aghbal, Bokkoya offshore and Boudinar normal faults which have been and still are potentially seismogenic [42] [46].

Finally, at depth, tomographic maps obtained by [54] show a low-velocity zone at $15 \mathrm{~km}$ depth near Al Ho- 
ceima; however, the resolution of the maps is not appropriate for determining accurate orientations. Instead, the higher resolution tomography obtained by [36] clearly shows that the aftershock hypocentres are located within high velocity zones at $5-15 \mathrm{~km}$ depth, whose orientation is in conformity with the chosen faults, which may not be an artifact of the used methodology.

\subsection{Seismic Hazard}

In order to predict which fault planes are most loaded by positive CSC and may be reactivated, we plotted the main known faults of the Al Hoceima area and run the program with Coulomb stress resolved onto planes having the same strike than the major faults recognized in the area.

Figures 7(D) and Figure 8 show CSC after the 2004 earthquake resolved onto the strikes of the regional fault planes located around the epicenter. The figures show that the faults around Al Hoceima city are not affected by an increase in stress, with the exception of the Nekor fault, the south-western segment of which is affected by an increase of about 7 bar. However, it should be emphasized that most stress was probably released through the very numerous aftershocks.

The time interval for the occurrence of the next event is for the moment difficult to determine because it depends on the tectonic load related to the plate motion of Nubia with respect to Eurasia, but also on the regional motion of blocks across the TASZ and the accommodation of motion by faults. Estimations should be possible when a larger and more precise GPS database will be available in the next years.

Anyway, CSC modeling is a tool which is, at a local scale $\left(10,000 \mathrm{~km}^{2}\right)$, an efficient alternative method to probabilistic and deterministic approaches of seismic hazard in the area [86] [87].

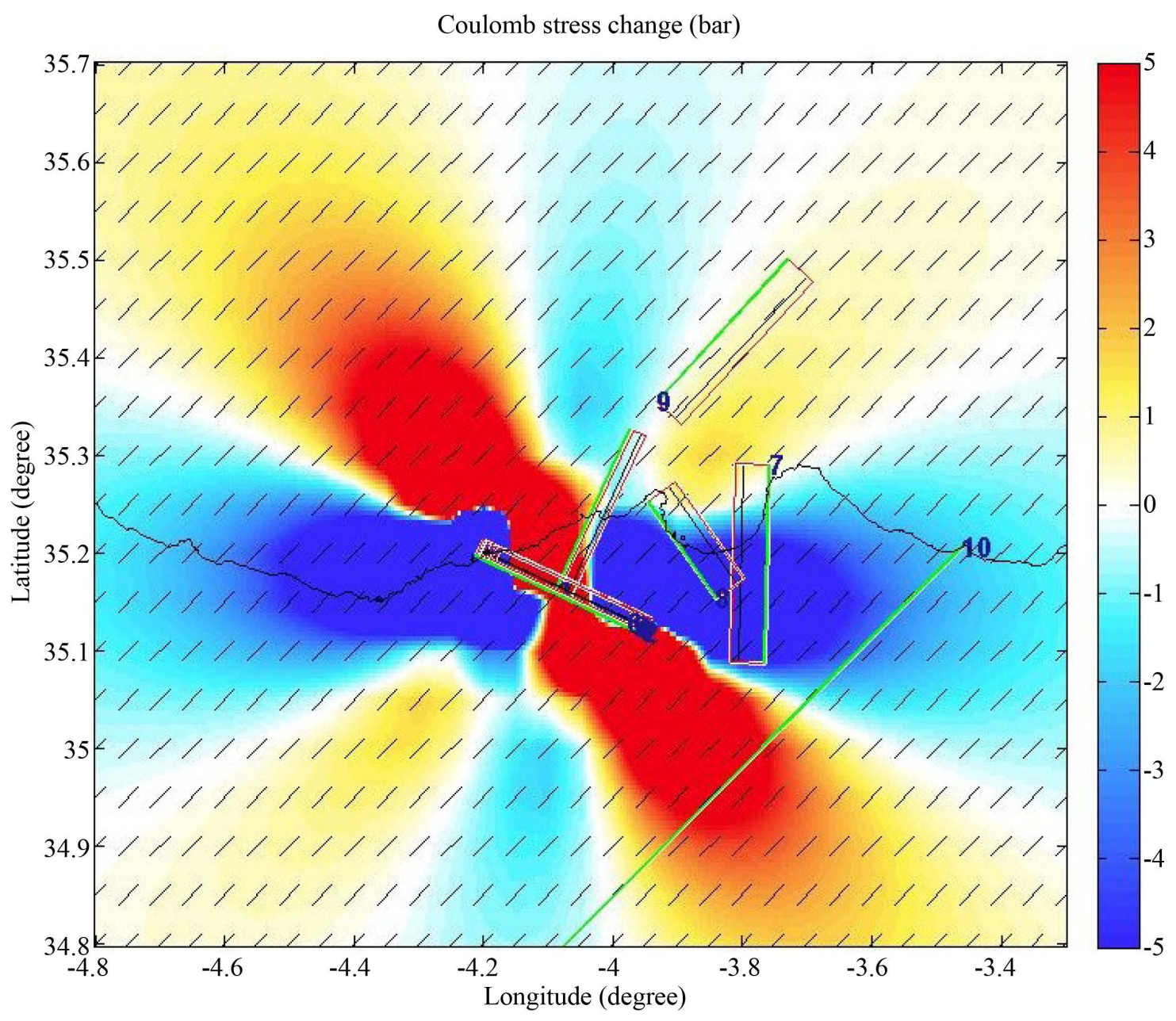

Figure 8. Results of CSC modeling of the 2004 earthquake on planes parallel to the Nekor fault. 


\section{Conclusions}

Coulomb modeling of the stress perturbations caused by the Al Hoceima earthquakes of 1994 and 2004 based on the compilation of all the studies carried out after both events, including seismological (location and depth of the main shocks and aftershocks), seismotectonic (source parameters, stress field), geotedic (GPS), tomographic and geological ones, leads to the conclusions that:

1) The 1994 earthquake is likely to have induced the 2004 one when adopting the most accurate epicenter locations, source fault traces and receiver fault planes. Motion along the N23E oriented Bousekkour-Aghbal fault in 1994 activated the eastern segment of an unknown NW-SE fault located at its southern end, which originated the 2004 earthquake.

2) The model also provides a suitable explanation for the distribution of the aftershocks' clusters.

3) Finally, prediction of the next event shows that it is likely to occur on NE-SW planes located to the NW (Bokkoya and offshore) and SE (reaching the Nekor fault) of the NW-SE fault, while Al Hoceima city will remain in a shadow zone.

\section{Acknowledgements}

This study was initiated within the TERRINA team of the GEOTEL Laboratory at the Institut Scientifique (Rabat). Files of the 1994 aftershocks were provided by Prof. S.O. El Alami before his retirement in 2006.

\section{References}

[1] Harris, R. (1998) Introduction to Special Section: Stress Triggers, Stress Shadows, and Implications for Seismic Hazard. Journal of Geophysical Research, 103, B10, 24, 347-24, 358. http://dx.doi.org/10.1029/98JB01576

[2] Freed, A.M. (2005) Earthquake Triggering by Static, Dynamic, and Postseismic Stress Transfer. Annual Reviews in Earth and Planetary Sciences, 33, 335-367. http://dx.doi.org/10.1146/annurev.earth.33.092203.122505

[3] Toda, S., Stein, R., Lin, J. and Sevilgen, V. (2008) Coulomb 3.1. User Guide. http://earthquake.usgs.gov/research/software/coulomb/

[4] King, G.C.P., Stein, R.S. and Lin, J. (1994) Static Stress Changes and the Triggering of Earthquakes. Bulletin of the Seismological Society of America, 84, 935-953.

[5] Toda, S., Stein, R.S., Richards-Dinger, K. and Bozkurt, S.B. (2005) Forecasting the Evolution of Seismicity in Southern California: Animations Built on Earthquake Stress Transfer. Journal of Geophysical Research, 110, B05S16, http://dx.doi.org/10.1029/2004JB003415

[6] Toda, S., Stein, R.S., Reasenberg, P.A., Dieterich, J.H. and Yoshida, A. (1998) Stress Transferred by the $1995 M_{w}=$ 6.9 Kobe, Japan, Shock: Effect on Aftershocks and Future Earthquake Probabilities. Journal of Geophysical Research, 103, B10, 24, 543-24, 565. http://dx.doi.org/10.1029/98JB00765

[7] Stein, R.S., Barka, A.A. and Dieterich, J.H. (1997) Progressive Failure on the North Anatolian Fault Since 1939 by Earthquake Stress Triggering. Geophysical Journal International, 128, 594-604. http://dx.doi.org/10.1111/j.1365-246X.1997.tb05321.x

[8] Buforn, E. and Udias, A. (2010) Azores-Tunisia, a Tectonically Complex Plate Boundary. Advances in Geophysics, 52, 139-182. http://dx.doi.org/10.1016/S0065-2687(10)52003-X

[9] Serpelloni, E., Vannucci, G., Pondrelli, S., Argnani, A., Casula, G., Anzidei, M., Baldi, P. and Gasperini, P. (2007) Kinematics of the Western Africa-Eurasia Plate Boundary from Focal Mechanisms and GPS Data. Geophysical Journal International, 169, 1180-1200. http://dx.doi.org/10.1111/j.1365-246X.2007.03367.x

[10] Cherkaoui, T.-E., Bensaid, I., Rimi, A. and Harnafi, M. (2007). Réseau sismologique du Département de Physique du Globe, 1937-2007. Univ. Mohammed V-Agdal, Institut Scientifique.

[11] El Alami, S.O., Tadili, B., Cherkaoui, T-E., Medina, F., Ramdani, M., Aït Brahim, L. and Harnafi, M. (1998) The Al Hoceima Earthquake of May, 26, 1994 and Its Aftershocks: A Seismotectonic Study. Annali di Geofisica, 41, 519537.

[12] Jabour, N., Kasmi, M., Menzhi, M., Birouk, A., Hni, L., Hahou, Y., Timoulaly, Y. and Sadrane, S. (2004) The February 24th, Al Hoceima Earthquake. CSEM-EMSC Newsletter, 21, 7-10.

[13] Akoglu, A.M., Cakir, Z., Meghraoui, M., Belabbes, S., El Alami, S.O., Ergintav, S. and Akyüz, H.S. (2006) The 1994-2004 Al Hoceima (Morocco) Earthquake Sequence: Conjugate Fault Ruptures Deduced from InSAR. Earth and Planetary Science Letters, 252, 467-480. http://dx.doi.org/10.1016/j.epsl.2006.10.010

[14] Bensaid, I., Cherkaoui, T.E., Medina, F., Caldeira, B., Buforn, E., Emran, A. and Hahou, Y. (2012) The 1992 Tafilalt 
Seismic Crisis (Anti-Atlas, Morocco). Journal of Seismology, 16, 35-53. http://dx.doi.org/10.1007/s10950-011-9248-5

[15] Avallone, A., Selvaggi, G., D’Anastasio, E., D’Agostino, N., Pietrantonio, G., Riguzzi, F., Serpelloni, E., Anzidei, M., Casula, G., Cecere, G., D’Ambrosio, C., De Martino, P., Devoti, R., Falco, L., Mattia, M., Rossi, M., Obrizzo, F., Tammaro, U. and Zarrilli, L. (2010) The RING Network: Improvements to a GPS Velocity Field in the Central Mediterranean. Annals of Geophysics, 53, 39-54.

[16] DeMets, C., Gordon, R.G. and Argus, D.F. (2010) Geologically Current Plate Motions. Geophysical Journal International, 181, 1-80. http://dx.doi.org/10.1111/j.1365-246X.2009.04491.x

[17] Chalouan, A. and Michard, A. (2004) The Alpine Rif Belt (Morocco): A Case of Mountain Building in a Subduction-Subduction-Transform Fault Triple Junction. Pure and Applied Geophysics, 161, 489-519. http://dx.doi.org/10.1007/s00024-003-2460-7

[18] Weijermars, R. (1987) The Palomares Brittle-Ductile Shear Zone of Southern Spain. Journal of Structural Geology, 9, 139-157. http://dx.doi.org/10.1016/0191-8141(87)90022-8

[19] Dillon, W.P., Robb, J.M., Greene, H.G. and Lucena, J.C. (1980) Evolution of the Continental Margin of Southern Spain and the Alboran Sea. Marine Geology, 36, 205-226. http://dx.doi.org/10.1016/0025-3227(80)90087-0

[20] Fadil, A., Vernant, P., McClusky, S., Reilinger, R., Gomez, F., Ben Sari, D., Mourabit, T., Feigl, K. and Barazangi, M. (2006) Active Tectonics of the Western Mediterranean: Geodetic Evidence for Rollback of a Delaminated Subcontinental Lithospheric Slab beneath the Rif Mountains, Morocco. Geology, 34, 529-532. http://dx.doi.org/10.1130/G22291.1

[21] De Larouzière, J., Bolze, J., Bordet, P., Hernandez, J., Montenat, C. and Ott d’Estevou, P. (1988) The Betic Segment of the Lithospheric Trans-Alboran Shear Zone during the Late Miocene. Tectonophysics, 52, 41-52. http://dx.doi.org/10.1016/0040-1951(88)90028-5

[22] Ammar, A., Mauffret, A., Gorini, C. and Jabour, H. (2007) The Tectonic Structure of the Alboran Margin of Morocco. Revista de la Sociedad Geologica de España, 20, 247-271.

[23] Tahayt, A., Mourabit, T., Rigo, A., Feigl, K.L., Fadil, A., McClusky, S., Reilinger, R., Serroukh, M., OuazzaniTouhami, A., Ben Sari, D. and Vernant, P. (2008) Mouvements actuels des blocs tectoniques dans l'arc Bético-Rifain à partir des mesures GPS entre 1999 et 2005. Comptes Rendus Geoscience, 340, 400-413. http://dx.doi.org/10.1016/j.crte.2008.02.003

[24] Vernant, P., Fadil, A., Mourabit, T., Ouazar, D., Koulali, A., Davila, J.M., Garate, J., McClusky, S. and Reilinger, R. (2010) Geodetic Constraints on Active Tectonics of the Western Mediterranean: Implications for the Kinematics and Dynamics of the Nubia-Eurasia Plate Boundary Zone. Journal of Geodynamics, 49, 123-129. http://dx.doi.org/10.1016/j.jog.2009.10.007

[25] Cunha, T.A., Matias, L.M., Terrinha, P., Negredo, A.M., Rosas, F., Fernandes, R.M.S. and Pinheiro, L.M. (2012) Neotectonics of the SW Iberia Margin, Gulf of Cadiz and Alboran Sea: A Reassessment Including Recent Structural, Seismic and Geodetic Data. Geophysical Journal International, 188, 850-872. http://dx.doi.org/10.1111/j.1365-246X.2011.05328.x

[26] Chalouan, A., Gil, A.J., Galindo-Zaldívar, J., Ahmamou, M., Ruano, P., de Lacy, M.C., Ruiz-Armenteros, A.M., Benmakhlouf, M. and Riguzzi, F. (2014) Active Faulting in the Frontal Rif Cordillera (Fes region, Morocco): Constraints from GPS Data. Journal of Geodynamics, 77, 110-122. http://dx.doi.org/10.1016/j.jog.2014.01.002

[27] Chalouan, A., Galindo-Zaldívar, J., Akil, M., Marín, C., Chabli, A., Ruano, P., Bargach, K., Sanz de Galdeano, C., Benmakhlouf, M., Ahmamou, M. and Gourari, L. (2006) Tectonic Wedge Escape in the Southwestern Front of the Rif Cordillera (Morocco). In: Moratti, G. and Chalouan, A., Eds., Tectonics of the Western Mediterranean and North Africa, Geological Society, London, Special Publication, Vol. 262, 101-118. http://dx.doi.org/10.1144/GSL.SP.2006.262.01.06

[28] Medina, F. (1995) Present-Day State of Stress in Northern Morocco from Focal Mechanism Analysis. Journal of Structural Geology, 17, 1035-1046. http://dx.doi.org/10.1016/0191-8141(94)00123-H

[29] Buforn, E., Sanz de Galdeano, C. and Udías, A. (1995) Seismotectonics of the Ibero-Maghrebian Region. Tectonophysics, 248, 247-261. http://dx.doi.org/10.1016/0040-1951(94)00276-F

[30] Buforn, E., Bezzeghoud, M., Udias, A. and Pro, C. (2004) Seismic Sources on the Iberia-African Plate Boundary and Their Tectonic Implications. Pure and Applied Geophysics, 161, 623-646. http://dx.doi.org/10.1007/s00024-003-2466-1

[31] Henares, J., Casado, C.L., de Galdeano, C.S., Delgado, J. and Peláez, J.A. (2003) Stress Fields in the Iberian-Maghrebi Region. Journal of Seismology, 7, 65-78. http://dx.doi.org/10.1023/A:1021294015027

[32] Medina, F. and El Alami, S.O. (2006) Focal Mechanisms and State of Stress in the Al Hoceima Area. Bulletin de l'Institut Scientifique, Section Sciences de la Terre, 28, 19-30.

[33] Stich, D., Serpelloni, E., Mancilla, F. and Morales, J. (2006) Kinematics of the Iberia-Maghreb Plate Contact from 
Seismic Moment Tensors and GPS Observations. Tectonophysics, 426, 295-317. http://dx.doi.org/10.1016/j.tecto.2006.08.004

[34] de Vicente, G., Cloetingh, S., Muñoz-Martın, A., Olaiz, A., Stich, D., Vegas, R., Galindo-Zaldıvar, J. and FernandezLozano, J. (2008) Inversion of Moment Tensor Focal Mechanisms for Active Stresses around the Microcontinent Iberia: Tectonic Implications. Tectonics, 27, Article ID: TC1009.

[35] Pedrera, A., Ruiz-Constán, A., Galindo-Zaldívar, J., Chalouan, A., Sanz de Galdeano, C., Marín-Lechado, C., Ruano, P., Benmakhlouf, M., Akil, M., López-Garrido, A.C., Chabli, A., Ahmamou, M. and González-Castillo, L. (2011) Is There an Active Subduction beneath the Gibraltar Orogenic Arc? Constraints from Pliocene to Present-Day Stress Field. Journal of Geodynamics, 52, 83-96. http://dx.doi.org/10.1016/j.jog.2010.12.003

[36] van der Woerd, J., Dorbath, C., Ousadou, F., Dorbath, L., Delouis, B., Jacques, E., Tapponnier, P., Hahou, Y., Menzhi, M., Frogneux, M. and Haessler, H. (2014) The Al Hoceima Mw 6.4 Earthquake of 24 February 2004 and Its Aftershocks Sequence. Journal of Geodynamics, 77, 89-109. http://dx.doi.org/10.1016/j.jog.2013.12.004

[37] Guillemin, M. and Houzay, J.P. (1982) Le Néogène post-nappe et le Quaternaire du Rif nord-oriental. Stratigraphie et tectonique des bassins de Melilla, du Kert, de Boudinar et du piedmont des Kebdana. Notes et Mémoires du Service géologique du Maroc, 314, 7-239.

[38] El Azzouzi, M., Bernard-Griffiths, J., Bellon, H., Maury, R.C., Piqué, A., Fourcade, S., Cotten, J. and Hernandez, J. (1999) Evolution des sources du volcanisme marocain au cours du Néogene. Comptes Rendus de l'Académie des Sciences de Paris, Série 2, Sciences de la Terre et des Planètes, 329, 95-102.

[39] Thauvin, S. (1971) La zone rifaine. In: Service géologique du Maroc, Ed., Ressources en eau du Maroc. Tome I: Domaines du Rif et du Maroc oriental, Notes et Mémoires du Service géologique du Maroc, Rabat, Vol. 231, 69-79.

[40] Azdimousa, A., Poupeau, G., Rezqi, H., Asebriy, L., Bourgois, J. and Ait Brahim, L. (2006) Géodynamique des bordures méridionales de la mer d'Alboran; application de la stratigraphie séquentielle dans le bassin néogène de Boudinar (Rif oriental, Maroc). Bulletin de l'Institut Scientifique, Rabat, Section Sciences de la Terre, 28, 9-18.

[41] Calvert, A., Gomez, F., Seber, D., Barazangi, M., Jabour, N., Ibenbrahim, A. and Demnati, A. (1997) An Integrated Geophysical Investigation of Recent Seismicity in the Al-Hoceima Region of North Morocco. Bulletin of the Seismological Society of America, 87, 637-651.

[42] D’Acremont, E., Gutscher, M-A., Rabaute, A., Mercier de Lépinay, B., Lafosse, M., Poort, J., Ammar, A., Tahayt, A., Le Roy, P., Smit, J., Do Couto, D., Cancouët, R., Prunier, C., Ercilla, G. and Gorini, C. (2014) High-Resolution Imagery of Active Faulting Offshore Al Hoceima. Tectonophysics, 632, 160-166. http://dx.doi.org/10.1016/j.tecto.2014.06.008

[43] Leblanc, D. and Olivier, P. (1984) Role of Strike-Slip Faults in the Betic-Rifian Orogeny. Tectonophysics, 101, 345355. http://dx.doi.org/10.1016/0040-1951(84)90120-3

[44] Cherkaoui, T-E. (1988) Fichier des séismes du Maroc et des régions limitrophes 1901-1984. Travaux de l’Institut Scientifique, Série Géologie et Géographie physique, 17, 1-158.

[45] Hatzfeld, D., Caillot, V., Cherkaoui, T-E., Jebli, H. and Medina, F. (1993) Microearthquake Seismicity and Fault Plane Solutions Study around the Nékor Strike-Slip Fault, Morocco. Earth and Planetary Science Letters, 120, 31-41. http://dx.doi.org/10.1016/0012-821X(93)90021-Z

[46] Poujol, A., Ritz, J-F., Tahayt, A., Vernant, P., Condomines, M., Blard, P-H., Billant, J., Vacher, L., Tibart, B., Hni, L. and Koulali Idrissi, A. (2014) Active Tectonics of the Northern Rif (Morocco) from Geomorphic and Geochronological Data. Journal of Geodynamics, 77, 70-88. http://dx.doi.org/10.1016/j.jog.2014.01.004

[47] Mourier, T. (1982) Etude géologique et structurale du Massif des Bokkoya (Rif Oriental, Maroc). 3ème Cycle Thesis, Orsay.

[48] Galindo-Zaldívar, J., Chalouan, A., Azzouz, O., Sanz de Galdeano, C., Anahnah, F., Ameza, L., Ruano, P., Pedrera, A., Ruiz-Constán, A., Marín-Lechado, C., Benmakhlouf, M., López-Garrido, A.V., Ahmamou, M., Saji, R., Roldán-García, F.J., Akil, M. and Chabli, A. (2009) Are the Seismological and Geological Observations of the Al Hoceima (Morocco, Rif) 2004 Earthquake $(M=6.3)$ Contradictory? Tectonophysics, 475, 59-67. http://dx.doi.org/10.1016/j.tecto.2008.11.018

[49] Fullea, J., Fernàndez, M., Afonso, J.C., Vergés, J. and Zeyen, H. (2010) The Structure and Evolution of the Lithosphere-Asthenosphere Boundary beneath the Atlantic-Mediterranean Transition Region. Lithos, 120, 74-95. http://dx.doi.org/10.1016/j.lithos.2010.03.003

[50] Mancilla, F., Stich, D., Morales, J., Julià, J., Diaz, J., Pazos, A., Cordoba, D., Pulgar, J.A., Ibarra, P., Harnafi, M. and Gonzalez-Lodeiro, F. (2012) Crustal Thickness Variations in Northern Morocco. Journal of Geophysical Research, 117, Article ID: B02312. http://dx.doi.org/10.1029/2011JB008608

[51] Rimi, A., Fernandez, M., Manar, A., Matsushima, J., Okubo, Y., Morel, J.L., Winckel, A. and Zeyen, H. (2005) Geothermal Anomalies and Analysis of Gravity, Fracturing and Magnetic Features in Morocco. World Geothermal Con- 
gress, Antalya, 24-29 April 2005, 1-10.

[52] Calvert, A., Sandvol, E., Seber, D., Barazangi, M., Roecker, S., Mourabit, T., Vidal, F., Alguacil, G. and Jabour, N. (2000) Geodynamic Evolution of the Lithosphere and Upper Mantle beneath the Alboran Region of the Western Mediterranean: Constraints from Travel time Tomography. Journal of Geophysical Research, 105, 10871-10898. http://dx.doi.org/10.1029/2000JB900024

[53] Serrano, I., Zhao, D., Morales, J. and Torcal, F. (2003) Seismic Tomography from Local Crustal Earthquakes beneath Eastern Rif Mountains of Morocco. Tectonophysics, 367, 187-201. http://dx.doi.org/10.1016/S0040-1951(03)00100-8

[54] Timoulali, Y., Djellit, H., Hahou, Y., Jabour, N. and Merrouch, R. (2014) New Evidence of Delamination in the Western Alboran Sea: Geodynamic Evolution of the Alboran Domain and Its Margins. Journal of Geodynamics, 117, 206216. http://dx.doi.org/10.1016/j.jog.2013.10.005

[55] Elmrabet, T. (2005) Les tremblements de terre majeurs dans la région du Maghreb, et leurs conséquences sur l’homme et l'environnement. Ed. CNRST-LAG, Rabat. (In Arabic)

[56] McKenzie, D. (1972) Active Tectonics of the Mediterranean Region. Geophysical Journal International, 30, 109-185. http://dx.doi.org/10.1111/j.1365-246X.1972.tb02351.x

[57] Udias, A., Lopez-Arroyo, A.L. and Mezcua, J. (1976) Seismotectonic of the Azores-Alboran Region. Tectonophysics, 31, 259-289. http://dx.doi.org/10.1016/0040-1951(76)90121-9

[58] El Alami, S.O., Tadili, B., Brahim, L.A. and Mouayn, I. (2004) Seismicity of Morocco for the period 1987-1994. Pure and Applied Geophysics, 161, 969-982. http://dx.doi.org/10.1007/s00024-003-2503-0

[59] Cherkaoui, T.E., Hatzfeld, D., Jebli, H., Medina, F. and Caillot, V. (1990) Etude microsismique de la région d’A1 Hoceima. Bulletin de l'Institut Scientifique, 14, 25-34.

[60] Buforn, E., Bezzeghoud, M., del Fresno, C., Borges, J.F., Madariaga, R. and Udias, A. (2005) Study of the Fracture Process of Alhoceima Earthquake (24/02/2004, Mw=6.2) from Regional and Teleseismic Data. Geophysical Research Abstracts, 7, Article ID: 05301.

[61] Tahayt, A., Feigl, K.L., Mourabit, T., Rigo, A., Reilinger, R., McClusky, S., Fadil, A., Berthier, E., Dorbath, L., Serroukh, M., Gomez, F. and Ben Sari, D. (2009) The Al Hoceima (Morocco) Earthquake of 24 February 2004, Analysis and Interpretation of Data from ENVISAT ASAR and SPOT5 Validated by Ground-Based Observations. Remote Sensing of Environment, 113, 306-316. http://dx.doi.org/10.1016/j.rse.2008.09.015

[62] Medina, F. (2008) Catalogue of Focal Mechanisms of Moroccan Earthquakes for the Period 1959-2007. Documents de l'Institut Scientifique Rabat, 23, 1-47.

[63] Stich, D., Martin, R. and Morales, J. (2010) Moment Tensor Inversion for Iberia-Maghreb Earthquakes 2005-2008. Tectonophysics, 483, 390-398. http://dx.doi.org/10.1016/j.tecto.2009.11.006

[64] Bensaid, I., Buforn, E., Cherkaoui, T.E., Medina, F. and Hahou, Y. (2011) New Fault-Plane Solutions of Moroccan Earthquakes for the 2005-2008 Period. Bulletin de l'Institut Scientifique, Rabat, Section Sciences de la Terre, 33, 4752.

[65] Medina, F., Bensaid, I. and Tangi, A. (2011) Catalogue of Focal Mechanisms of Moroccan Earthquakes for the Period 1959-2007; Analysis of Parameters. Bulletin de l'Institut Scientifique, Rabat, Section Sciences de la Terre, 33, 37-46.

[66] Beeler, N.M., Simpson, R.W., Hickman, S.H. and Lockner, D.A. (2000) Pore Fluid Pressure, Apparent Friction, and Coulomb Failure. Journal of Geophysical Research, 105, 25533-25542. http://dx.doi.org/10.1029/2000JB900119

[67] Steacey, S., Nalbant, S.S., McCloskey, J., Nostro, C., Scotti, O. and Baumont, D. (2005) Onto What Planes Should Coulomb Stress Perturbations Be Resolved? Journal of Geophysical Research, 110, Article ID: B05S15.

[68] Ait Brahim, L., Nakhcha, C., Tadili, B., El Mrabet, T. and Jabour, N. (2004) Structural Analysis and Interpretation of the Surface Deformations of the February 24th, 2004 Al Hoceima Earthquake. CSEM-EMSC Newsletter, 21, 7-10.

[69] Dorbath, L., Hahou, Y., Delouis, B., Dorbath, C., Van Der Woerde, J., Badrane, S., Frogneux, M., Haessler, H., Jacques, E., Menzhi, M. and Tapponnier, P. (2005) Etudes sismologiques sur le séisme d'Al Hoceima: Localisation et mécanisme du choc principal et des répliques, contraintes et structure de la zone épicentrale. Colloque International Séisme d'Al Hoceima: Bilan et perspectives, Al Hoceima, 24-26 février 2005, 22.

[70] Bezzeghoud, M. and Buforn, E. (1999) Source Parameters of the 1992 Melilla (Spain, Mw = 4.8), 1994 Alhoceima (Morocco, $M w=5.8$ ) and 1994 Mascara (Algeria, $M w=5.7$ ) Earthquakes and Seismotectonic Implications. Bulletin of the Seismological Society of America, 89, 359-372.

[71] Cakir, Z., Meghraoui, M., Akoglu, A.M., Jabour, N., Belabbes, S. and Ait Brahim, L. (2006) Surface Deformation Associated with the Mw 6.4, 24 February 2004 Al Hoceima, Morocco, Earthquake Deduced from InSAR: Implications for the Active Tectonics Along North Africa. Bulletin of the Seismological Society of America, 96, 59-68. http://dx.doi.org/10.1785/0120050108

[72] Biggs, J., Bergman, E., Emmerson, B., Funning, G.J., Jackson, J., Parsons, B. and Wright, T.J. (2006) Fault Identifica- 
tion for Buried Strike-Slip Earthquakes Using InSAR: The 1994 and 2004 Al Hoceima, Morocco Earthquakes. Geophysical Journal International, 166, 1347-1362. http://dx.doi.org/10.1111/j.1365-246X.2006.03071.x

[73] González, P.J., Palano, M. and Fernández, J. (2010) Study of the Present-Day Tectonics and Seismogenetic Sources of the Al-Hoceima Region (Morocco) Using GPS and MTInsar. Proceedings of the Fringe 2009 Workshop, 30 November-4 December 2009, Frascati. ESA Special Publication-677, 7 p. http://earth.eo.esa.int/workshops/fringe09/proceedings/papers/p1_6gonz.pdf

[74] Angelier, J. and Mechler, P. (1977) Sur une méthode graphique de recherche des contraintes principales également utilisable en tectonique et en séismologie: La méthode des dièdres droits. Bulletin de la Société géologique de France, 19, 1309-1318. http://dx.doi.org/10.2113/gssgfbull.S7-XIX.6.1309

[75] Marrett, R.A. and Allmendinger, R.W. (1990) Kinematic Analysis of Fault-Slip Data. Journal of Structural Geology, 12, 973-986. http://dx.doi.org/10.1016/0191-8141(90)90093-E

[76] Angelier, J. and Goguel, J. (1979) Sur une méthode simple de détermination des axes principaux des contraintes pour une population de failles. Comptes Rendus de l'Académie des Sciences de Paris, 288, 307-310.

[77] Etchecopar, A., Vasseur, G. and Daignieres, M. (1981) An Inverse Problem in Microtectonics for the Determination of Stress Tensors from Fault Striation Analysis. Journal of Structural Geology, 3, 51-65. http://dx.doi.org/10.1016/0191-8141(81)90056-0

[78] Michael, A.J. (1984) Determination of Stress from Slip Data: Faults and Folds. Journal of Geophysical Research, 90, 11517-11526. http://dx.doi.org/10.1029/JB089iB13p11517

[79] Michael, A.J. (1987) Use of Focal Mechanisms to Determine Stress: A Control Study. Journal of Geophysical Research, 92, 357-368. http://dx.doi.org/10.1029/JB092iB01p00357

[80] Carey-Gailhardis, E. and Mercier, J-L. (1987) A Numerical Method for Determining the State of Stress Using Focal Mechanisms of Earthquake Populations: Application to Tibetan Teleseisms and Microseismicity of Southern Peru. Earth and Planetary Science Letters, 82, 165-179. http://dx.doi.org/10.1016/0012-821X(87)90117-8

[81] Rivera, L. and Cisternas, A. (1990) Stress Tensor and Fault Plane Solutions for a Population of Earthquakes. Bulletin of the Seismological Society of America, 80, 600-614.

[82] Gephart, J. (1990) A Fortran Program for Inverting Fault/Slickenside and Earthquake Focal Mechanism Data to Obtain the Regional Stress Tensor. Computers and Geosciences, 16, 953-989. http://dx.doi.org/10.1016/0098-3004(90)90105-3

[83] Reches, Z., Baer, G. and Hatzor, Y. (1992) Constraints on the Strength of the Upper Crust from Stress Inversion of Slip Data. Journal of Geophysical Research, 97, 12481-12493. http://dx.doi.org/10.1029/90JB02258

[84] Stich, D., Mancilla, F., Baumont, D. and Morales, J. (2005) Source Analysis of the Mw 6.32004 Al Hoceima Earthquake (Morocco) Using Regional Apparent Source Time Functions. Journal of Geophysical Research, 110, Article ID: B06306. http://dx.doi.org/10.1029/2004JB003366

[85] Angelier, J. (1990) Inversion of Field Data in Fault Tectonics to Obtain the Regional Stress—III. A New Rapid Direct Inversion Method by Analytical Means. Geophysical Journal International, 103, 363-376. http://dx.doi.org/10.1111/j.1365-246X.1990.tb01777.x

[86] Ramdani, M. and Tadili, B. (1982) Evaluation du risque sismique dans la région de Nador. Bulletin de l'Institut Scientifique, 6, 53-61.

[87] Vaccari, F., Tadili, B., El Qadi, A., Ramdani, M., Ait Brahim, L. and Limouri, M. (2001) Deterministic Seismic Hazard Assessment for North Morocco. Journal of Seismology and Earthquake Engineering, 3, 1-12.

[88] Zitellini, N., Gràcia, E., Matias, L., Terrinha, P., Abreu, M.A., DeAlteriis, G., Henriet, J.P., Dañobeitia, J.J., Masson, D.J., Mulder, T., Ramella, R., Somoza, L. and Diez, S. (2009) The Quest of the Africa-Eurasia Plate Boundary West of the Strait of Gibraltar. Earth and Planetary Science Letters, 280, 13-50. http://dx.doi.org/10.1016/j.epsl.2008.12.005

[89] Maurer, G. (1968) Les montagnes du Rif central: Etude géomorphologique. Doctorat d’Etat Thesis, Paris.

[90] Andrieux, J. (1971) La structure du Rif central. Etude des relations entre la tectonique en compression et les nappes de glissement dans un tronçon de la chaîne alpine. Notes et Mémoires du Service géologique du Maroc, 235, 1-155.

[91] Suter, G. (1980) Carte structurale de la chaîne rifaine au 1/500,000. Notes et Mémoires du Service géologique du Maroc, 245b.

[92] Frizon de Lamotte, D. (1982) Contribution à l'étude de l'évolution structurale du Rif oriental. Notes et Mémoires du Service géologique du Maroc, 314, 239-309.

[93] Morel, J-L. (1987) Evolution récente de l'orogène rifain et de son avant-pays depuis la fin de la mise en place des nappes (Rif, Maroc). Mém. Géodiffusion, Orsay. 
Scientific Research Publishing (SCIRP) is one of the largest Open Access journal publishers. It is currently publishing more than 200 open access, online, peer-reviewed journals covering a wide range of academic disciplines. SCIRP serves the worldwide academic communities and contributes to the progress and application of science with its publication.

Other selected journals from SCIRP are listed as below. Submit your manuscript to us via either submit@scirp.org or Online Submission Portal.
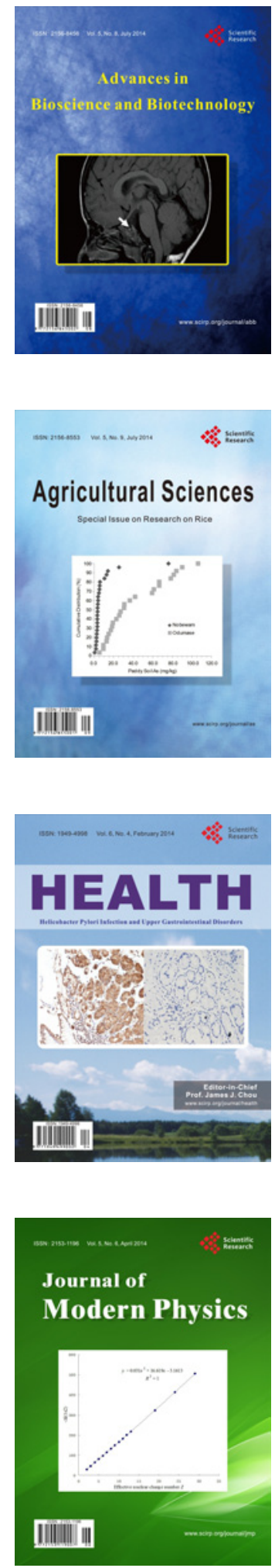
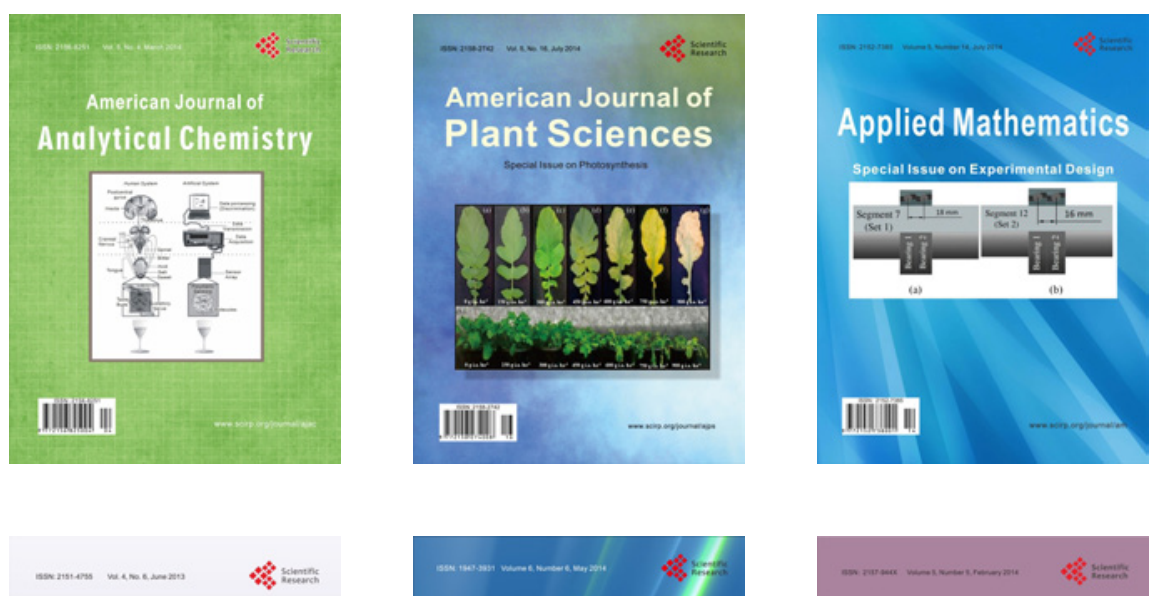

Creative Education
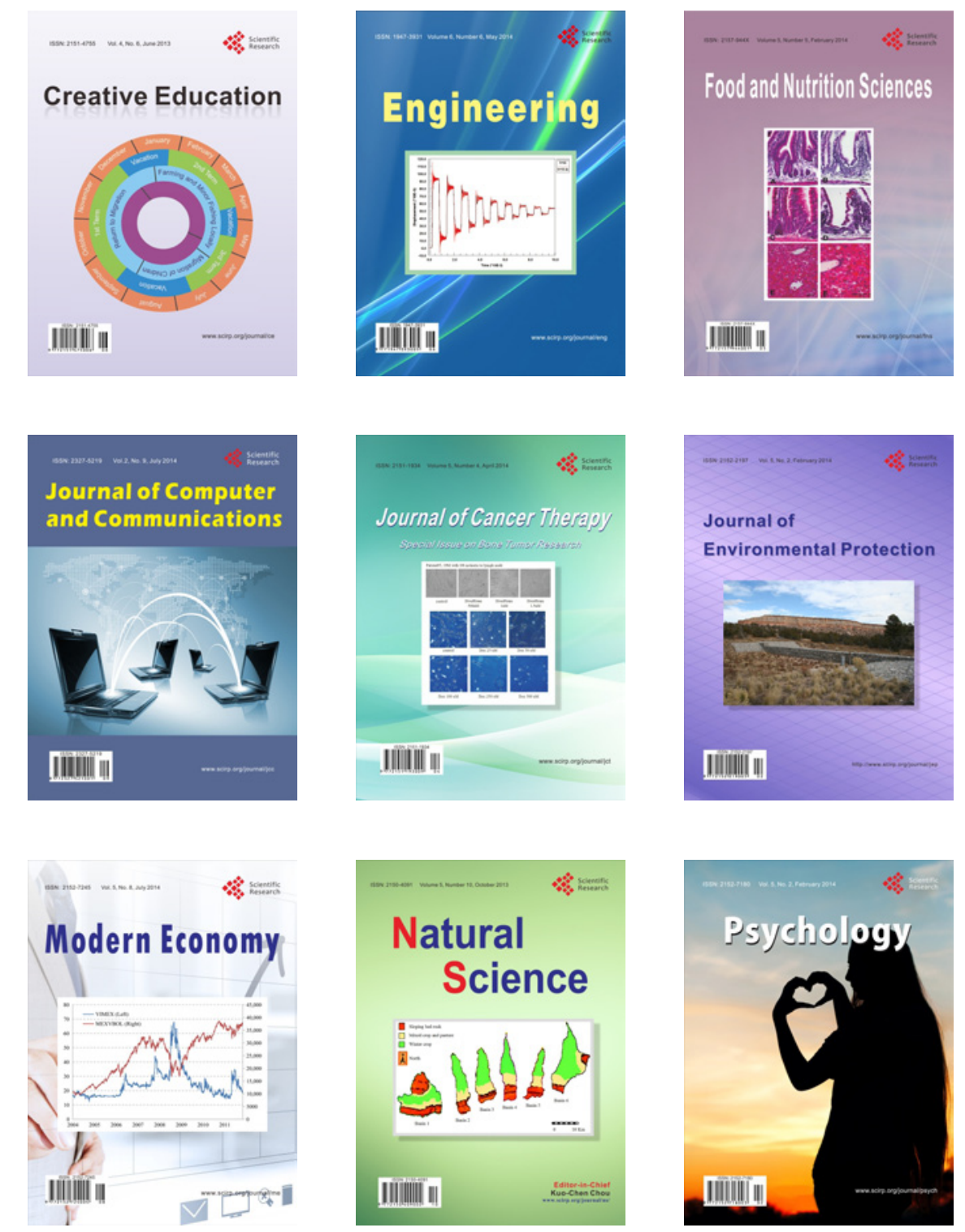